\title{
Intense seismicity during the 2014-15 Bárðarbunga-Holuhraun rifting event, Iceland, reveals the nature of dike-induced earthquakes and caldera collapse mechanisms
}

\author{
Thorbjörg Ágústsdóttir ${ }^{1,2}$, Tom Winder ${ }^{1}$, Jennifer Woods ${ }^{1}$, Robert S. White ${ }^{1}$, Tim \\ Greenfield $^{1}$, Bryndís Brandsdóttir ${ }^{3}$ \\ ${ }^{1}$ University of Cambridge, Department of Earth Sciences, Bullard Laboratories, Cambridge, UK \\ ${ }^{2}$ Now at Iceland GeoSurvey, ReykjavÃnk, Iceland \\ ${ }^{3}$ Institute of Earth Sciences, Science Institute, University of Iceland, ReykjavÃnk, Iceland
}

\section{Key Points:}

- Dike induces strike-slip faulting in rift fabric, with fault slip direction governed by orientation of faults with respect to dike opening

- Caldera seismicity reveals piecemeal trapdoor-style (asymmetric) collapse accommodated by normal faulting on multiple inward dipping faults

- Caldera collapse seismicity occurs primarily $2-8 \mathrm{~km}$ below surface, indicating the upper limit for a magma reservoir. 


\begin{abstract}
Over two weeks in August 2014 magma propagated 48km laterally from Bárðarbunga volcano before erupting at Holuhraun for 6 months, accompanied by collapse of the caldera. A dense seismic network recorded over 47,000 earthquakes before, during and after the rifting event. More than 30,000 earthquakes delineate the segmented dike intrusion. Earthquake source mechanisms show exclusively strike-slip faulting, occurring near the base of the dike along pre-existing weaknesses aligned with the rift fabric, while the dike widened largely aseismically. The slip-sense of faulting is controlled by the orientation of the dike relative to the local rift fabric, demonstrated by an abrupt change from right- to left-lateral faulting as the dike turns to propagate from an easterly to a northerly direction. Approximately 4,000 earthquakes associated with the caldera collapse delineate an inner caldera fault zone, with good correlation to geodetic observations. Caldera subsidence was largely aseismic, with seismicity accounting for $10 \%$ or less of the geodetic moment. Approximately $90 \%$ of the seismic moment release occurred on the northern rim, suggesting an asymmetric collapse. Well-constrained focal mechanisms reveal sub-vertical arrays of normal faults, with fault planes dipping inward at $\sim 60^{\circ} \pm 9^{\circ}$, along both the north and south caldera margins. These steep normal faults strike sub-parallel to the caldera rims, with slip vectors pointing towards the center of subsidence. The maximum depth of seismicity defines the base of the seismogenic crust under Bárðarbunga as $6 \mathrm{~km}$ b.s.l., in broad agreement with constraints from geodesy and geobarometry for the minimum depth to the melt storage region.
\end{abstract}

\title{
1 Introduction
}

\subsection{Geological setting}

Iceland sits astride the slow-spreading Mid-Atlantic ridge on the divergent plate boundary between the North American and the Eurasian plates. It is subaerial due to dynamic support and increased crustal thickness caused by enhanced melt production from an underlying mantle plume [White and McKenzie, 1989; Jenkins et al., 2018]. Iceland has experienced voluminous basaltic volcanism since the early Tertiary, forming a band of thickened crust crossing the North Atlantic along the Greenland-Iceland-Faroes Ridge.

En-echelon stepping rift segments (volcanic systems) define the subaerial ridge axis in Iceland, which is subdivided into distinct volcanic zones (yellow in Figure 1). The aver- 
age spreading direction in Iceland is $106^{\circ}$ at a rate of $18.2 \mathrm{~mm} / \mathrm{y}$ [DeMets et al., 2010], approximately $10^{\circ}$ oblique to the rift-normal direction in the Northern Volcanic Zone (NVZ) (inset Figure 1). Volcanic systems within the rift zones of Iceland comprise a central volcano and transecting fissure swarm. Each system has distinct petrological and structural characteristics [Saemundsson, 1978; Einarsson, 2008]. Crustal formation occurs by magmatism within these zones of divergence. Eruptions may take place in the central volcano or anywhere within its fissure swarm, though most of the melt that forms beneath the volcanic systems never reaches the surface but freezes and cools at depth, in dikes or sills [e.g. White et al., 2011, 2018]. Seismically imaged volcanoes in Iceland reveal shallow magma storage regions typically found at 3-6 km depth b.s.1.. [Gudmundsson et al., 1994; Brandsdóttir et al., 1997; Alfaro et al., 2007; Greenfield et al., 2016].

Stresses gradually accumulate in the brittle upper crust during the intervals between significant deformation events, such as dike intrusions or large earthquakes [Einarsson, 2008]. During rifting events, a large amount of volcano-tectonic (VT) seismicity is generated in the upper crust as extensional stresses are released by surface fracturing, graben formation and dike emplacement [e.g. Einarsson and Brandsdóttir, 1980; Battaglia et al., 2005; Grandin et al., 2011; Wright et al., 2012; Sigmundsson et al., 2015; Ágústsdóttir et al., 2016]. Rifting in Iceland is typically episodic, with repeat intervals of tens of decades.

\subsection{Bárðarbunga volcanic system}

The Bárðarbunga volcanic system lies on the boundary between the Northern Volcanic Zone (NVZ) and the Eastern Volcanic Zone (EVZ) in central Iceland (Figure 1), close to the center of the Iceland mantle plume [e.g. Wolfe et al., 1997; Darbyshire et al., 1998]. It is one of the largest volcanic systems in Iceland. The central volcano Bárðarbunga consists of a 500-800 m deep ice-filled caldera rising $2009 \mathrm{~m}$ above sea level and covering an area of approximately $80 \mathrm{~km}^{2}$, with a $190 \mathrm{~km}$ long fissure swarm [Jóhannesson and Saemundsson, 1998; Larsen et al., 2013; Larsen and Gudmundsson, 2015]. The fissure swarm can be accurately mapped where it extends out from under the Vatnajökull glacier to the SSW and NNE (Figure 1). This reveals a significant change in strike from $\sim 040-045^{\circ}$ in the southwest (Veiðivötn fissure swarm) to $\sim 025^{\circ}$ in the northeast (Dyngjuháls fissure swarm). Gravity studies suggest that dense intrusions have radiated at depth along the fissure swarm in both directions [Gudmundsson and Högnadóttir, 2007]. 
The Bárðarbunga volcanic system has been highly active in the Holocene, with at least 26 eruptions in the last 1000 years [Thordarson and Larsen, 2007; Larsen and Gudmundsson, 2015]. The recent eruption history is not fully known [Brandsdóttir and Pálsson, 2014] as the Holocene eruption frequency is mainly based on tephra layers [Óladóttir et al., 2011] not detectable on the ice sheet. The dominant magma type is tholeiitic basalt but geochemically distinct silicic magma may erupt where volcanic fissures intersect the Torfajökull volcanic system [Larsen and Gudmundsson, 2015]. The Bárðarbunga volcanic system has generated extensive lava flows, reaching the coast in both northern and southwestern Iceland [Larsen and Gudmundsson, 2015; Svavarsdóttir et al., 2017]. The most recent pre-2014 lava flows on the northern arm of the fissure swarm are the 18th and 19th century Holuhraun lavas [Hartley and Thordarson, 2013; Guttormsson, 2014] and on the southern arm are the 1862-1864 Tröllahraun lavas [Thorarinsson and Sigvaldason, 1972]. These basaltic lavas have chemical signatures indicative of the Bárðarbunga volcanic system [Hartley and Thordarson, 2013; Sigmarsson and Halldórsson, 2015; Svavarsdóttir et al., 2017]. By analysing a wide span of Bárðarbunga Holocene lava samples north of Vatnajökulll, Svavarsdóttir et al. [2017] showed that the isotopic fingerprint of Bárðarbunga is wider than previously thought, covering the 1996 Gjálp values and contradicting the $\mathrm{Sr}$ isotope analysis of Sigmarsson et al. [2000] who reported that the Gjálp erupted materials have the geochemical fingerprint of the neighbouring Grímsvötn volcano.

\subsubsection{Seismicity in Bárðarbunga}

Bárðarbunga central volcano has been seismically active since the beginning of seismic monitoring in the 1970s. Seismicity rates were elevated between 1974 and 1996, peaking with the subglacial 1996 Gjálp eruption, located about $12 \mathrm{~km}$ south of the caldera [Einarsson et al., 1997] (thick orange line, Figure 1). Seismicity preceding the 1996 eruption originated along the Bárðarbunga caldera rim and migrated southwards towards the Gjálp eruption site over a period of 24 hours [Einarsson et al., 1997].

Moment tensor solutions from the 1974-1996 sequence show thrust faulting with a significant non-double-couple component at hypocentral depths ranging from $3.5-15 \mathrm{~km}$ below the surface [Ekström, 1994; Nettles and Ekström, 1998; Konstantinou et al., 2003; Tkalčić et al., 2009; Bjarnason, 2014]. At the time, four telemetered analog seismic stations were in operation within $60 \mathrm{~km}$ distance of Bárðarbunga, the nearest at a distance of $15 \mathrm{~km}$. These were operated by the Science Institute, University of Iceland. The clos- 


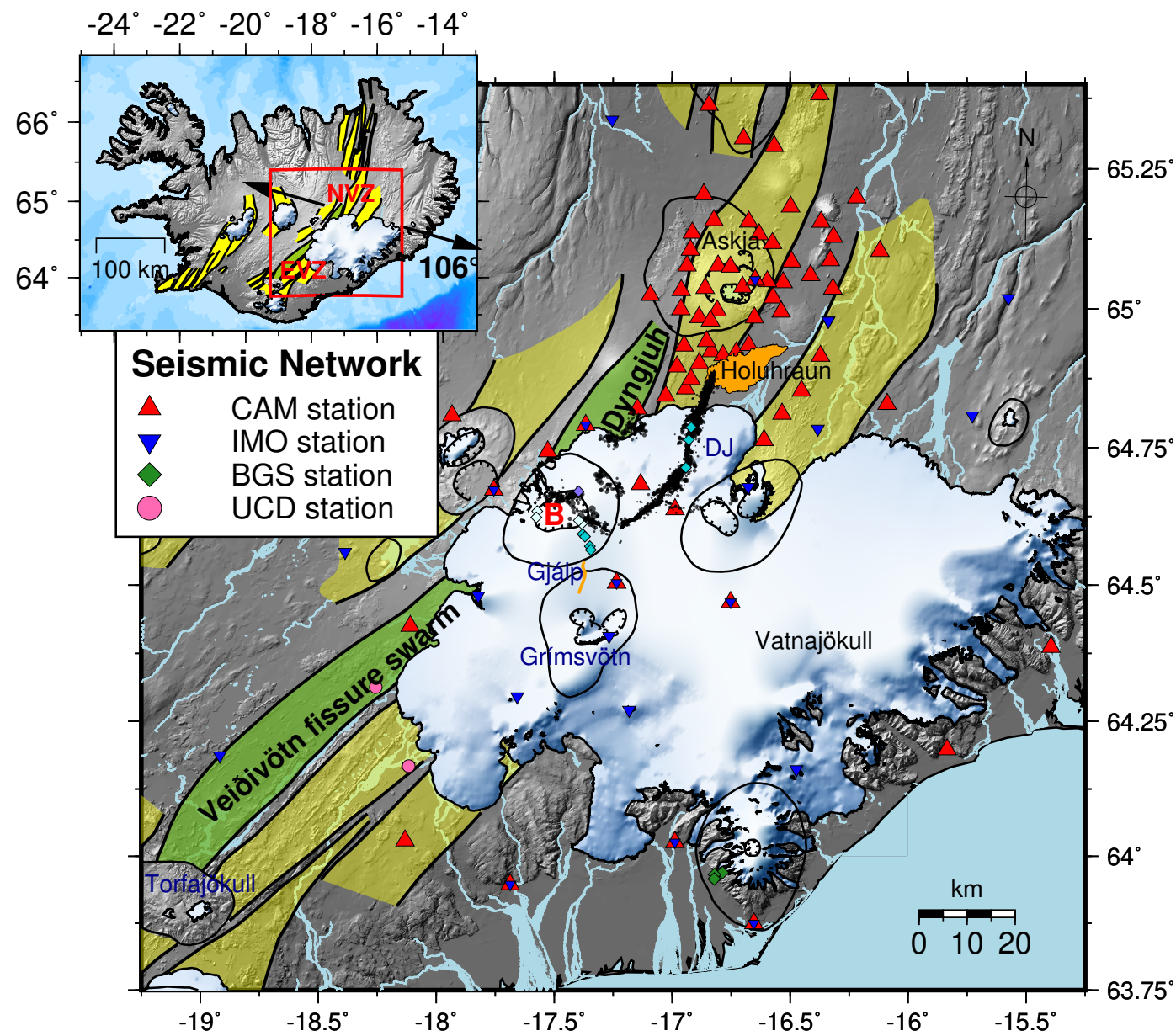

Figure 1. Location map and station distribution. Black circles are refined earthquake locations from the 2014-2015 Bárðarbunga-Holuhraun rifting event, B stands for Bárðarbunga caldera. The Bárðarbunga volcanic system is shaded green, with subaerial fissure swarm branches labeled: Veiðivötn fissure swarm (to the SW), Dyngjuháls fissure swarm (to the NE); other volcanic systems yellow. Red triangles mark Cambridge seismometers, blue inverted triangles IMO seismometers (see label for seismic stations). For full network configurations during survey period see Figure S1. The orange line is the 1996 Gjálp eruption fissure; diamonds are ice cauldrons color-coded by formation year [Gudmundsson et al., 2016] (white formed in the two decades prior to the rifting episode, turquoise formed in 2014, purple in 2015), open circles delineate central volcanoes and ticked lines calderas, shaded topography in grey with glaciers in white. Inset shows location on a simplified tectonic map of Iceland [Einarsson and Saemundsson, 1987]. Arrows show the average spreading direction in the Iceland region of $106^{\circ}$ [DeMets et al., 2010], with the Eastern Volcanic Zone (EVZ) and the Northern Volcanic Zone (NVZ) labeled. 
est digital station, run by the Icelandic Meteorological Office (IMO), was at a distance of $50 \mathrm{~km}$ [Einarsson et al., 1997; Jakobsdóttir, 2008]. The study reported here of the 20142015 Bárðarbunga-Holuhraun dike intrusion and caldera subsidence uses a much denser seismic network than any previous study, with the closest station at $\sim 10 \mathrm{~km}$ distance from the caldera (see Figures 1 and S1), resulting in better constrained hypocenters and moment tensors. The station closest to the dike was at $\sim 0.5 \mathrm{~km}$ distance.

\subsubsection{The 2014-15 Bárðarbunga Holuhraun rifting event}

The most recent rifting event in Iceland began in the Bárðarbunga volcanic system on 16 August 2014, when a segmented, lateral dike intrusion propagated $48 \mathrm{~km}$ from the central volcano over 2 weeks [Sigmundsson et al., 2015; Ágústsdóttir et al., 2016], before erupting in a topographic low, reoccupying craters from the previous eruption at Holuhraun. The initial 4 hour long eruption on 29 August 2014 was followed by a major eruption which lasted 6 months, between 31 August 2014 and 27 February 2015. The Holuhraun lava flow covered $84 \mathrm{~km}^{2}$ with an estimated bulk volume of $1.4-1.6 \mathrm{~km}^{3}$, making it the largest eruption in Iceland since the 1783-1784 Laki eruption [Gíslason, 2015; Pedersen et al., 2017]. Subsidence in Bárðarbunga caldera was first observed two weeks into the eruption [Sigmundsson et al., 2015; Gudmundsson et al., 2016]. In the two decades prior to the dike intrusion, minor geothermal activity manifested as two small ice cauldrons on the western Bárðarbunga caldera rim and two on the southeastern rim (white diamonds, Figure 1). However, since August 2014, geothermal activity has increased, with eleven new ice cauldrons forming on the caldera rims and three cauldrons formed by small subglacial eruptions along the dike path [Gudmundsson et al., 2016; Reynolds et al., 2017] (turquoise and purple diamonds, Figure 1).

The dike intrusion was accompanied by intense seismicity along the dike path, marking the dike propagation, and along the caldera rim as Bárðarbunga began to subside [Sigmundsson et al., 2015; Ágústsdóttir et al., 2016; Woods et al., 2019]. The volcano-tectonic (VT) seismicity before, during and after the 2014-2015 Bárðarbunga-Holuhraun rifting event is the focus of this study (Figure 1). Analysis of the variation in faulting styles along the dike path gives insight into the nature of the dike-induced seismicity, and careful examination of the caldera earthquakes provides a clearer picture of the mechanism of collapse of Bárðarbunga. 


\subsection{Caldera collapse}

Calderas occur worldwide in a wide range of tectonic settings, but caldera-forming eruptions are rare in recent geological history. Calderas are typically polygenetic and undergo several minor eruptions from their flanks, rift zones or centrally, both before and after the main caldera-forming eruption [Acocella, 2007]. Caldera collapses vary greatly in the amount of subsidence, ranging from a few meters to a kilometer [Acocella, 2007; Branney and Acocella, 2015]. Basaltic calderas typically form during effusive eruptions that usually persist for days or months [Newhall and Dzurisin, 1988]. The timing of caldera collapse is not well known, and it is unclear whether subsidence occurs as a response to magma evacuation, or whether it commences at a later stage, as the reservoir roof pushes out the magma.

From 1900 to present, only eight other caldera collapses have been observed (Katmai 1912, Fernandina 1968, Tolbachik 1975-1976, Rabaul 1983-1985, Pinatubo 1991, Miyakejima 2000, Piton de la Fournaise 2007 and Halema'uma'u 2018). The limited number of modern examples and the scarcity of geophysical data leaves open the question of whether collapse generally occurs suddenly or gradually over the course of an eruption. The 2014-2015 Bárðarbunga caldera collapse, along with the recent 2018 Halema'uma'u caldera collapse, are amongst the world's best geophysically recorded. Gudmundsson et al. [2016] describe the gradual, incremental nature of the Bárðarbunga caldera collapse, totalling $65 \mathrm{~m}$ and creating a $1.8 \mathrm{~km}^{3}$ subsidence bowl in the ice-surface, driven by the evacuation of an underlying magma reservoir. Subsidence stopped when the eruption came to an end.

Five main types of caldera collapse mechanism have been identified: down-sag, piston, funnel, piecemeal and trapdoor, which can all be viewed as end-members [Walker, 1984; Lipman, 1997; Cole et al., 2005; Acocella, 2007; Branney and Acocella, 2015]. Piston, trapdoor and piecemeal are the most commonly observed in the geological record. Piston-type caldera collapses are bordered by a ring fault, with coherent subsidence of a central block. Piecemeal collapses result from the differential vertical movement of multiple independent internally fractured blocks [e.g. Neal et al., 2018]. Trapdoor collapses form asymmetric depressions, with an un-faulted hinge [e.g. Jónsson et al., 2005]. Caldera collapse can occur: 1) incrementally, along a pre-existing structure; 2) continuously, which may be expected at any type of volcano; and 3) suddenly, due to cavity formation at depth 
where there are no pre-existing structures [Acocella, 2007; Ruch et al., 2012]. Cashman and Giordano [2014] argue there is growing evidence that caldera-forming eruptions are not all fed by single magma bodies, and that it does not necessarily require a long time period to accumulate an eruptible quantity of melt. This is in agreement with previous work in Iceland by Pálmason [1971] and Brandsdóttir et al. [1997] which suggests that the melt plumbing systems of large Icelandic central volcanoes comprise a complex network of sills, with magma rising within high density intrusive complexes within the crust.

\section{Methods}

The dense local seismic network used in this study comprises 72, 3-component broadband instruments installed in the NVZ and EVZ, providing good azimuthal coverage of the study area (Figures 1, S1). The network geometry remained stable throughout the study period, meaning that the event detection threshold only varied due to changes in the noise level, here dependent on a combination of atmospheric noise (weather), eruption vent tremor and the rate of seismic activity.

\subsection{Earthquake catalogs}

To obtain the earthquake catalogs we use the following workflow: 1) earthquakes were automatically detected using Coalescence Microseismic Mapping software (CMM) [Drew et al., 2013] with the velocity model of Ágústsdóttir et al. [2016] (Figure S2); 2) earthquake locations were calculated using NonLinLoc using automatically detected phase arrival times [Lomax et al., 2000]; 3) earthquake magnitudes $\left(\mathrm{M}_{L}\right)$ were calculated following the method of Greenfield et al. [2018]; 4) a subset of events was manually picked to obtain refined phase arrival times and P-wave polarity picks, and located with NonLinLoc; 5) earthquake source mechanisms were investigated using the refined locations and polarity picks obtained in step (4) to calculate fault plane solutions; 6) locations of the entire automatic catalog were refined by cross-correlation and relative relocation. A combination of the results from (4) and (6) are used to produce the final catalog of locations with refined absolute and relative locations (referred to hereafter as refined locations: these are used in all figures in this paper). (Datasets S1, S2 and Tables S1, S2). 


\subsubsection{Manually refined earthquake locations and focal mechanisms}

Approximately 1000 events were manually picked, producing over 50,200 P-phase picks and 38,000 S-phase picks. Locations generated using these refined phase arrival times give average uncertainties for the dike events of $0.3 \mathrm{~km}$ horizontally and $0.8 \mathrm{~km}$ vertically, increasing from $0.3 \mathrm{~km}$ in the north to $1 \mathrm{~km}$ in the south, and for the caldera events $0.4-0.5 \mathrm{~km}$ horizontally and $0.9 \mathrm{~km}$ vertically (datasets S3, S4 and Tables S3, S4).

Earthquake source mechanisms were investigated by full moment tensor inversions of P-wave polarity data using the Bayesian moment tensor solution program MTfit [Pugh $\&$ White, 2018]. For an event to pass the quality control it had to produce a reliable fault plane solution (FPS) with consistent phase picks, and stations well distributed over the focal sphere. Events with fewer than 8 P-picks and 4 S-picks were automatically discarded. Only high quality FPSs are interpreted and presented in this study.

\subsection{Cross-correlation and relative relocation}

Earthquakes in the caldera and along the dike path were relatively relocated using sub-sample differential travel times, following the method of Woods et al. [2019]. Precise and accurate locations were obtained via a three-step process consisting of: 1) refinement of differential travel times by cross-correlation using the GISMO toolkit [Reyes \& West, 2011]; 2) relative relocation with hypoDD [Waldhauser and Ellsworth, 2000]; and 3) realignment with manually refined locations for absolute locations.

\subsubsection{Calculation of differential travel times by cross-correlation}

Traces were bandpass filtered between 2 and $20 \mathrm{~Hz}$, and cross-correlated over a short window (-0.5 s to $2 \mathrm{~s}$ ) around the automatic pick time for both $\mathrm{P}$ and S phase arrivals, on vertical and horizontal components respectively. Event traces were then realigned on the maximum cross-correlation (CC) coefficient to achieve sub-sample differential travel times (example given in Supplementary Figure S3). Events in the caldera and along the dike were processed separately, with caldera events cross-correlated in one run and dike events cross-correlated in multiple runs following the method of Woods et al. [2019]. A minimum CC coefficient threshold of 0.6 was imposed and traces requiring a shift (time lag) of $>0.5 \mathrm{~s}$ were discarded. Noisy stations were found to be liable to produce spurious results and so were not used ( $\sim 30 \%$ of stations). 


\subsubsection{Relative relocation with hypoDD}

Relative relocation of the hypocenters using the differential travel times was carried out with hypoDD, using a simple 1D block velocity model shown in Supplementary Figure S2. Again, the caldera and dike events were processed separately. To remain within computational limits, the minimum CC coefficient was increased at this stage. For the caldera events, approximately 30 million refined differential travel times were used (an average of 8500 per event), with an average $\mathrm{CC}$ coefficient of 0.80 . Observations were then weighted by the square of the $\mathrm{CC}$ coefficient. Since relocations are relative, events that were unclustered or not located in the main hypoDD cluster (i.e. with locations relative to only a handful of other events) were discarded. Discarded locations amounted to $~ 350$ out of 3500 , or $\sim 10 \%$ of the caldera events. This included both low signal-to-noise ratio events, some of the largest caldera earthquakes where waveforms were clipped and those with unique onsets (having too few similar events with which to correlate and relocate with this method). For the dike events, a variable CC coefficient threshold was used along the dike path such that approximately 4200 refined differential travel times were used per event, with an average $\mathrm{CC}$ coefficient of 0.76 . Dike events discarded in the process were $\sim 2000$ out of 43000 , or $4.5 \%$. The multiple subsets of dike events were aligned with respect to each other and then with the manually refined locations following the procedure described in Supplementary Text S1 and Figures S3-S5.

The cross-correlation and relative relocation procedure markedly improves the spatial resolution of the seismic image, collapsing the hypocenters into distinct clusters. Whilst absolute location uncertainties remain as quoted earlier, relative location uncertainties of the relocated events are on the order of $100 \mathrm{~m}$ (for detailed discussions of the uncertainties see Woods et al. [2019]). Relative uncertainties are related to many factors [Got et al., 1994], but notably decrease with an increasing number of events and differential travel time observations, which are very large in our case. However, uncertainty also arises from the velocity model used, particularly in depth.

\subsection{Seismic moment release calculation for $M_{w}>4$ earthquakes}

Local earthquake magnitudes calculated using the method of Greenfield et al. [2018] saturate at $\mathrm{M}_{L} \sim 3.5$, resulting in a significant underestimation of the seismic moment released by the earthquakes with $\mathrm{M}_{w}>4$ that occurred during the collapse of Bardarbunga 
caldera. To avoid this, we match the magnitudes of $\mathrm{M}_{w}>4$ earthquakes reported in the ISC catalog [?] to our refined earthquake locations. This enables us to calculate both the total seismic moment release during the collapse, and the moment release at each of the southern and northern margins.

\section{Results}

We present precise and accurate cross-correlated and relatively relocated earthquake locations and source mechanisms for the entire Bárðarbunga-Holuhraun rifting event and the associated caldera collapse. The rifting event is divided into three main periods: intrusion (2 weeks, 16-31 August 2014), eruption (6 months, September 2014 to February 2015) and post-eruption (6 months, March to mid-August 2015). Comparison is also made with the eight months preceding the intrusion (January to mid-August 2014).

\subsection{Temporal and spatial evolution of dike seismicity}

No earthquakes were detected along the dike path before the rifting event in 2014 . On 16 August 2014, at 03:45 UTC, activity started in the Bárðarbunga caldera with two earthquakes of $\mathrm{M}_{L}>2.5$ in the SE corner (Figure S6), followed closely by a handful of smaller events in the same area. The largest event occurred at 04:10 at the southeastern caldera boundary. At around 05:00 two $\mathrm{M}_{L}>2.1$ caldera events occurred inside the eastern caldera rim, approximately $2 \mathrm{~km} \mathrm{NNE}$ of the 4 am sequence (orange dots in Figure S6). The caldera was only active for two hours before the dike propagation began at around 05:45 (black arrow Figure S6). The seismicity suggests that the dike originated about $0.5 \mathrm{~km}$ inside the southeast side of the caldera (Figure S6).

Of the 41,000 earthquakes detected along the dike path (Figures 2, 3, 4), 82\% occurred during the two-week-long intrusive period, with seismicity concentrated at the dike tip at $\sim 6 \mathrm{~km}$ depth b.s.1.. Large-scale dike segments (S1-S5, Figures 2 and 3) were emplaced by episodic intrusion of many smaller segments with similar orientations. Each of the main segments became seismically quiet once a new segment had intruded beyond it, producing the step-like propagation of seismicity apparent in Figure 3d.

A $3.5 \mathrm{~km}$ long seismic gap is observed in the dike seismicity, between segments 1 and 2, where the dike turns a $90^{\circ}$ corner to the north-east (Figure 2 first panel and Figure 3a). The dike propagated aseismically across this gap in $4 \mathrm{hr}$. This is the only seismic 


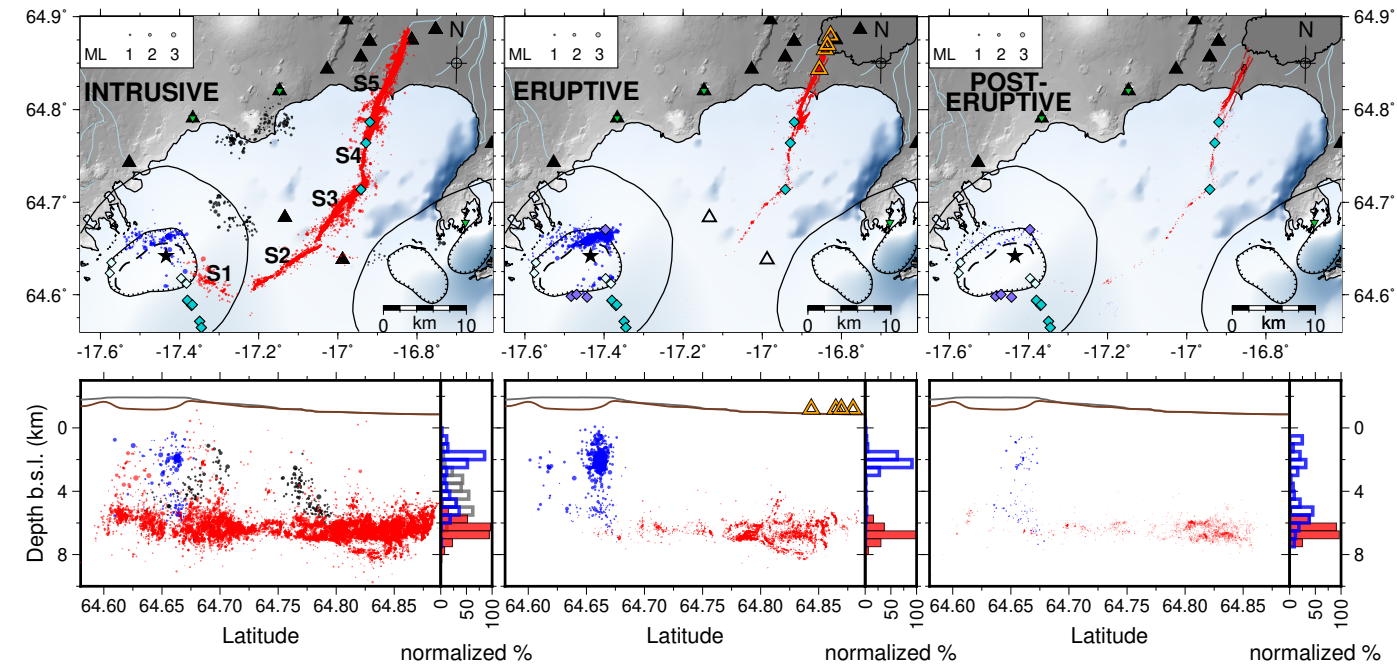

Figure 2. Seismicity during the intrusive, eruptive and post-eruptive periods, shown in map and depth view (latitude versus depth, with depth histogram). Dike earthquakes in red, caldera earthquakes in blue, and triggered earthquakes in dark grey. All earthquakes scaled by magnitude. Cambridge seismic stations indicated by black triangles, IMO stations by green inverted triangles. The black star represents the center of subsidence and black dashed line a possible inner caldera fault observed by InSAR data acquired 17-18 September 2014 [Gudmundsson et al., 2016]. Diamonds are ice cauldrons, color-coded by year of formation: lights blue formed before 2014, turquoise formed in 2014, purple in 2015. Open orange triangles mark subaerial eruption vents. In cross-sections glacier surface is shown in grey and caldera bedrock in brown [Björnsson and Einarsson, 1990]. 
gap observed along the dike's path during its emplacement. A similar seismic gap was observed during the 1975-1984 Krafla rifting episode, where repeated dike intrusions propagated aseismically over $\sim 3 \mathrm{~km}$ distance on the northern side of Krafla caldera [Einarsson and Brandsdóttir, 1980].

During the eruption, seismicity became concentrated along the distal $25 \mathrm{~km}$ of the dike (between the northernmost cauldron and the eruption site), north of $64.74^{\circ} \mathrm{N}$. The transport of melt over the first $20 \mathrm{~km}$ of the dike path occurred aseismically during the eruption (Figures 2, 3, 4). Spaans and Hooper [2018] suggest that in this region, under the glacier, earlier undetected intrusions may have accommodated most of the regional extension accumulated over the past 200 years. In contrast, no rifting is known to have occurred in the Holuhraun region since the early 18th century, resulting in a $\sim 4$ m extension deficit [Hartley and Thordarson, 2013; Ruch et al., 2016]. As a consequence, the dike opening was greatest along the distal end of the dike [Sigmundsson et al., 2015; Spaans and Hooper, 2018] where significantly more seismicity was induced. Network geometry was comparable during the intrusive and eruptive periods and so the aseismic melt transport is a robust observation.

Figure 2 is an overview of the seismicity associated with the rifting event, with caldera events colored blue and dike events red. Notably, the caldera events all occur at shallower depth levels than the dike. As the dike propagated forward it also induced seismicity in adjacent areas of high background strain rates (dark grey dots). This induced seismicity shut down when positive Coulomb stress lobes migrated past the swarm regions and negative stress shadows expanded into them, clamping the faults [Green et al., 2015]. The dike opening also triggered seismicity further north as the lobes of positive Coulomb stress extended into a region of ongoing intense tectonic seismicity [Greenfield et al., 2018].

The depth of seismicity along the dike during the intrusive, eruptive and post-eruptive periods remains similar, mostly confined to $5-8 \mathrm{~km}$ depth b.s.l. (Figure 2). The dike is modeled as extending almost to the surface along its length [Sigmundsson et al., 2015; Spaans and Hooper, 2018] and breached the surface at several locations (e.g. beneath the ice cauldrons [Reynolds et al., 2017], and at the main fissure site [Pedersen et al., 2017]). No seismicity shallower than 4-5 km b.s.l. was observed under the eruptive fissure, although melt clearly flowed from the dike to the surface. Similarly, no shallow seis- 

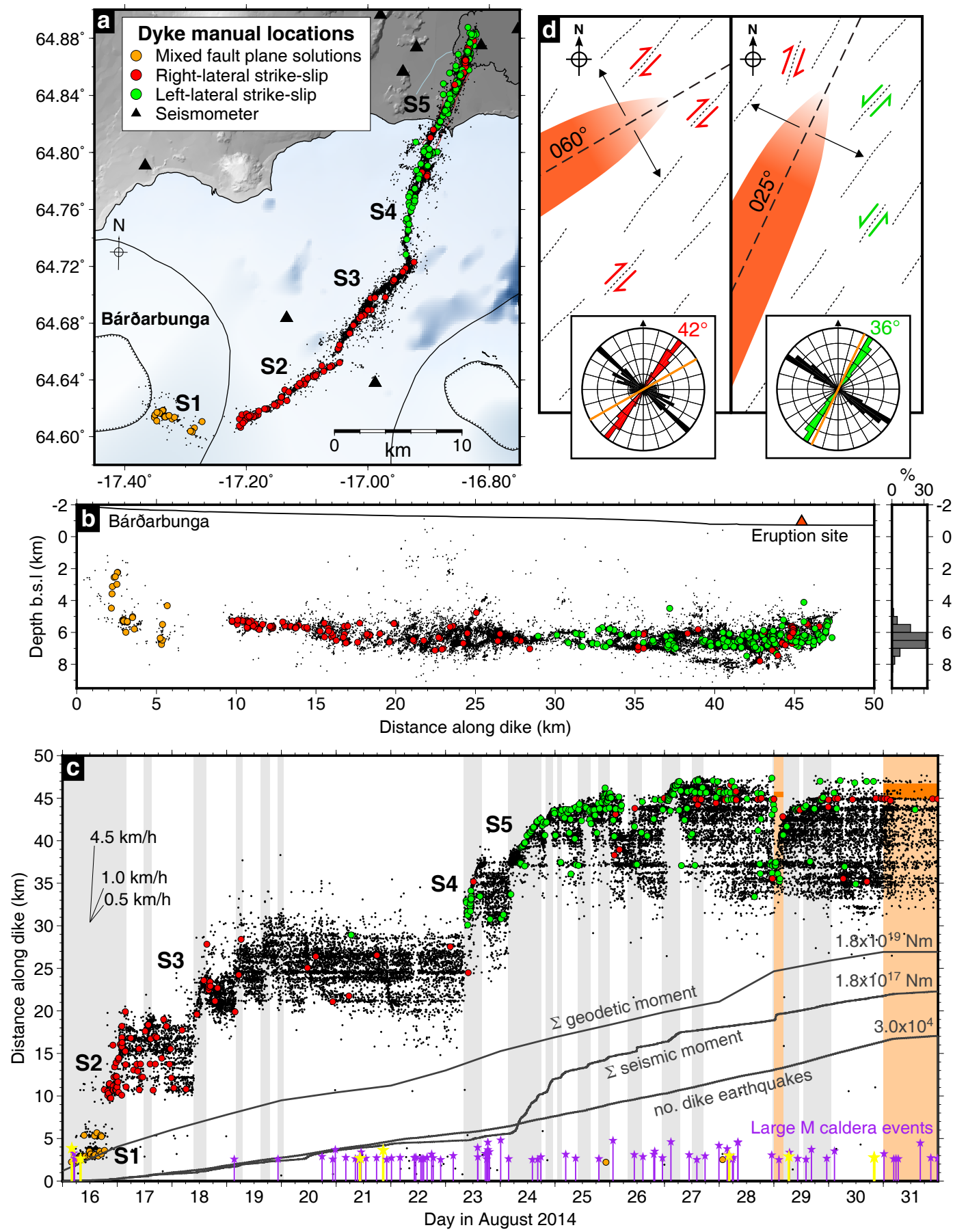

Figure 3. Dike earthquake locations and source mechanisms during the dike propagation. Earthquake hypocenters shown in a) map view, b) depth cross-section (with histogram) and c) distance along dike through time, with dike segments labeled. Refined (cross-correlated and relatively-relocated) earthquake locations shown by black dots, with manually analyzed events color-coded by source mechanism (see key). In c), cumulative number of dike earthquakes, seismic moment and geodetic moment shown by grey lines (note difference in scale); occurrence of caldera earthquakes shown as purple (northern rim) and yellow (southern rim) pegs, scaled by magnitude. Schematic fracture mechanisms and observed fault strikes (rose diagrams) shown in d) for segments S2 (right-lateral strike-slip faulting) and S5 (dominantly left-lateral strike-slip faulting). Rose diagrams for each segment shown in Supplementary Flgüre S7, Text S2-S3. 
micity was observed beneath the ice cauldrons, except some low-frequency earthquakes in their vicinity (at $\sim 4 \mathrm{~km}$ b.s.l.) indicating that small batches of melt escaped upward from the main dike pathway [Woods et al., 2018]. Based on detailed analysis of dike segment 5, Woods et al. [2019] show that seismicity is induced only where the combined stresses from the dike opening and regional extension are sufficient to induce failure of pre-existing weaknesses. This occurs towards the base of the dike (see Figure 7 in Woods et al. [2019]), near the brittle-ductile boundary, where ambient differential stresses from plate spreading are largest. At shallower depths, ambient differential stresses are unlikely to be sufficient to induce earthquakes in the weak, heavily fractured rock, and the dike opening is largely aseismic.

There is a marked drop in seismicity rate at the onset of the sustained eruption on 31 August (Figures 3 and 4). The same pattern is observed for the short-lived eruption on 29 August and on 5 September when another short lived eruption started $2 \mathrm{~km}$ south of the main fissure (Figure 4). A sharp decrease in seismicity rates as an eruption starts is a common observation in Icelandic volcanoes [Einarsson, 2018], and may indicate a reduction in conduit pressure as a pathway to the surface is opened and magma flows out.

Several horizontal bands of seismicity are apparent in Figure 4, indicating points of persistent seismicity along the dike path, with the most prominent at $36-38 \mathrm{~km}$, where the graben is widest and where the largest dike events occurred in September 2014. The other fainter horizontal bands further back along the dike path are also located at small en-echelon steps in the dike path. Stresses at the terminations of these small-scale dike segments remain elevated after the dike has intruded past, and may continue to evolve during and after the eruption, causing this persistent seismicity.

The eruption persisted for 6 months, gradually developing from a $\sim 1.6 \mathrm{~km}$ long eruptive fissure to a single vent [Pedersen et al., 2017]. From late January 2015 the eruption was abating [Pedersen et al., 2017], signalled by a decrease in the frequency of caldera events (fewer star-head pegs, Figure 4) and in a reduced rate of dike seismicity in February 2015. After the eruption ended on 27 February 2015 the dike seismicity rate increases, illuminating almost the entire dike path. This observation is caused by the lowering of the detection threshold of the seismic network $\left(\mathrm{M}_{c}\right.$ Table S5) when the eruptive vent noise ceased. 


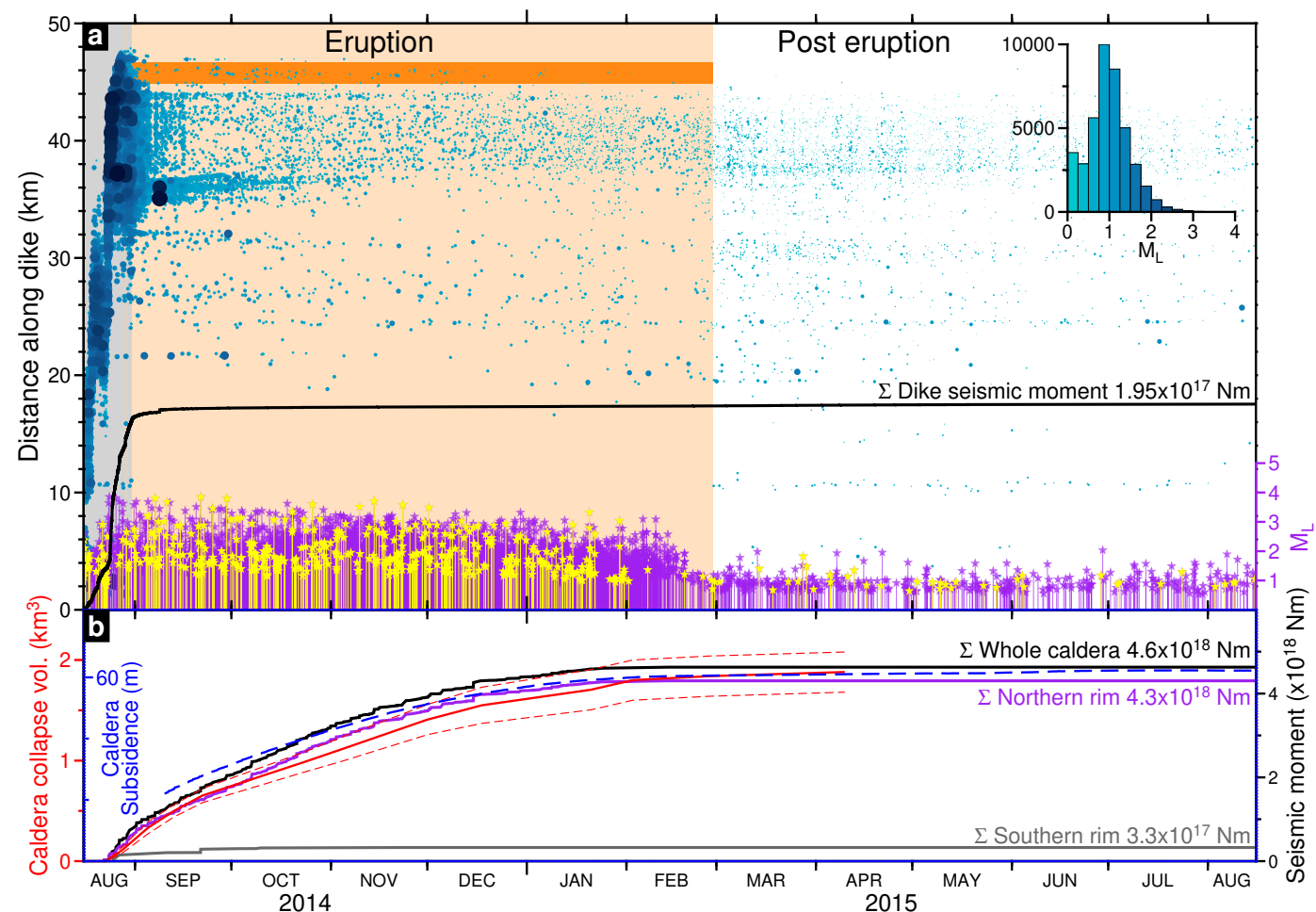

Figure 4. Seismicity along the dike path and in the caldera from 16 August 2014 to 16 August 2015. (a): Earthquakes along the dike path colored and scaled by magnitude, with magnitude-frequency histogram inset and cumulative seismic moment in black. Intrusive period shaded in grey (see Figure 3c for zoom-in); eruptive period in light orange, with eruption fissure dark orange. Caldera earthquakes shown by purple (northern rim) and yellow (southern rim) star-head pegs, with local magnitude indicated by peg height - note that local magnitude saturates at $\mathrm{M}_{L} \sim 3.5$. (b): caldera subsidence and seismic moment release through time. Moment release (black line) is calculated from $\mathrm{M}_{w}>4$ earthquakes in the ISC catalog [?] matched to the refined hypocenter locations presented in this study for subdivision by location (northern rim in purple, southern rim in grey). Measured caldera subsidence (blue) and calculated caldera collapse volume (red) from Gudmundsson et al. [2016]. 
Magnitudes of dike propagation earthquakes range between $M_{L} 0-4$, with the largest magnitudes at the leading edge and at points of continued seismicity along the dike path (Figure 4). During and after the eruption the earthquakes are considerably smaller, with $\mathrm{M}_{L}<2$, but exhibit similar earthquake source mechanisms to the intrusive period. Woods et al. [2019] show that after the initial dike opening the seismicity rate is related to magma pressure changes (dike inflation/deflation) and exhibits a 'post-opening' decay (i.e. continued seismicity at a decaying rate, as expected after a dike tip passes [Segall et al., 2013]).

\subsubsection{Dike earthquake source mechanisms}

Manually analysed earthquakes along the whole dike trajectory provide well constrained fault plane solutions (FPSs). Phase and polarity picks from the small and emergent events during the first day (segment 1) of dike propagation were difficult to make, but thereafter the high signal-to-noise ratio of events gave clean, reliable phase and polarity picks (segments 2-5).

FPSs along the whole dike path show exclusively double-couple strike-slip failure, despite the setting of an opening dike. Combined with the two orders of magnitude deficit between the geodetic and seismic moment associated with the dike opening (Figure 3), this indicates that the dike opened primarily by aseismic Mode I failure [Ágústsdóttir et al., 2016]. The stresses produced by the opening, combined with pre-existing tectonic stresses, induced abundant strike-slip seismicity on pre-existing weaknesses around the base of the dike [Woods et al., 2019].

Investigating the FPSs along the entire dike path expands on the results of Ágústsdóttir et al. [2016] who analysed just the northernmost $15 \mathrm{~km}$ of the dike path (segment 5). In segment 1 , where the dike radially exits the main edifice (orange dots in Figure 3), there is no obvious pattern in the FPSs (a mixture of strike-slip, normal and thrust faulting). The FPS strikes are similar to the strike of the segment $\left(\sim 130^{\circ}\right.$, Figure S7); the variable dips and rakes may be due to interaction with the central volcano edifice and to some extent due to the uncertainty in the FPSs in this less well-constrained segment. In segments 2 and 3 (Figure 3), right-lateral strike-slip faulting is observed as the dike turns a $90^{\circ}$ corner and propagates to the north-east away from the central volcano edifice. In segments 4 and 5, there is an abrupt change to left-lateral strike-slip faulting as the dike turns and propagates in a more northerly direction. This indicates that though the over- 
all dike path is governed by the lowest energy pathway, largely influenced by overburden pressure [Heimisson et al., 2015], the orientation of dike-induced seismicity is controlled by the pre-existing rift fabric. Where the dike propagation direction was to the east of this rift fabric in segments 2 and 3, right-lateral failure was induced (Figure 3e), and in segments 4 and 5 where it propagated in a more northerly direction, to the west of the fabric, left-lateral failure was induced (Figure 3f). Importantly, the dike orientation remained rotated to the east of the normal to the regional spreading direction ( $\sim 16^{\circ}$ throughout). This shows that it is not the orientation of the dike relative to the spreading direction that controls the style of faulting.

\subsection{Onset and evolution of the caldera collapse}

In the eight months prior to the intrusion, seismicity was confined to the northeastern part of the central volcano, perhaps marking a minor dike intrusion to the NE (top left panel Figure 5). Minor seismic activity was observed in the southeastern corner of the caldera 2 hours prior to the initiation of the dike intrusion (section 3.1). From late evening on 20 August 2014, four days after the dike exited the caldera and began propagating into the northeastern fissure swarm, there was a significant increase in seismicity in the caldera. This correlates with an 81 hour stalling of the dike, and the initiation of a long sequence of $\mathrm{M}_{w}>4\left(\mathrm{M}_{L}>\sim 3\right)$ events, marking the onset of caldera collapse (Figures 4 and 5).

\subsubsection{Caldera seismicity January 2014-August 2015: comparing pre-intrusive, in- trusive, eruptive and post-eruptive periods}

Over 70\% of the approximately 4,000 events that were detected and located in Bárðarbunga caldera occurred during the eruptive period (Figure 5), associated with collapse of the caldera. The earthquake distribution correlates well with geodetic observations outlining an inner caldera rim [Gudmundsson et al., 2016] (black dashed line, Figures 2 and 5). The spatial distribution of the earthquakes during the intrusive, eruptive and post-eruptive periods are markedly different to that of the pre-intrusive period (Figure 5). During the eight months prior to the onset of the intrusion, seismicity extended northeastwards from the caldera and was not concentrated along the caldera ring-fault structure (top left panel, Figure 5). During the two-week intrusive period, the 6-month eruptive period and the post-eruptive period, activity was observed both on the northern side of the caldera and 
in the southeastern corner, but primarily concentrated along the northern caldera ring-fault structure.

Pre-intrusive activity is confined to the northeastern corner of the caldera and northeastern flank of the central volcano (top left panel, Figure 5), at depths of 4-7 km b.s.l. with $\mathrm{M}_{L}$ 0.3-2.0. This seismicity occurred mostly during a swarm in May 2014. Earthquakes were again observed in this region during the first two days of the dike intrusion, while it was covered by a lobe of positive Coulomb stress induced by the dike opening. However, as the dike propagated further north these faults fell into a stress shadow, causing seismicity to cease [Green et al., 2015]. Earthquakes were also detected in this area in 1975-1985 [Einarsson, 1991; Björnsson and Einarsson, 1990] and 1995-2007 [Jakobsdóttir, 2008].

Caldera seismicity during the dike propagation occurred primarily in two clusters, both aligned with the caldera ring-fault structure (Figure 5). The main cluster outlines an inner caldera fault on the northern side, with events located at $0-4 \mathrm{~km}$ depth b.s.l. with magnitudes $\mathrm{M}_{L}$ 0.6-3.4 (though note that $\mathrm{M}_{L}$ saturates at $\sim 3.5$; these events reach $\mathrm{M}_{w}$ 5.8 [Gudmundsson et al., 2016]. The other cluster is located on the north-west side of the caldera (confined to the mapped caldera rim and west of it), with events at 4-7 km depth b.s.l. and of smaller magnitudes $\left(\mathrm{M}_{L}\right.$ 0.6-1.9). Seismicity was also observed in the south-east and east of the caldera, but at significantly lower rates. This observation is exaggerated slightly by the cross-correlation and relative relocation method employed (Section 2.2.2, Text S1), whereby events that are few in number and with low signal to noise ratio are poorly correlated and thus excluded from the refined catalog. The unrefined automatic catalog (Figure S8), shows that even without this bias there were considerably fewer events detected on the south side. During the intrusive period, seismic activity started in the north-east corner, outlining the inner caldera fault. From there, the activity spread west along the northern caldera rim during the intrusive and eruptive period, forming the deeper cluster. Despite locating over 4000 caldera events, we do not find any depth propagation in time indicative of a rupture starting from above or below.

Caldera seismicity during the eruption clearly outlines an inner caldera fault, with events of $\mathrm{M}_{L}$ 0.7-3.4 ( $\mathrm{M}_{w}$ up to 5.8) at 0-4 km depth b.s.l. (lower left panel Figure 5). This inner caldera fault is also mapped using satellite derived (InSAR) observations [Gudmundsson et al., 2016]. The more westerly activity continues to occur on and around the 

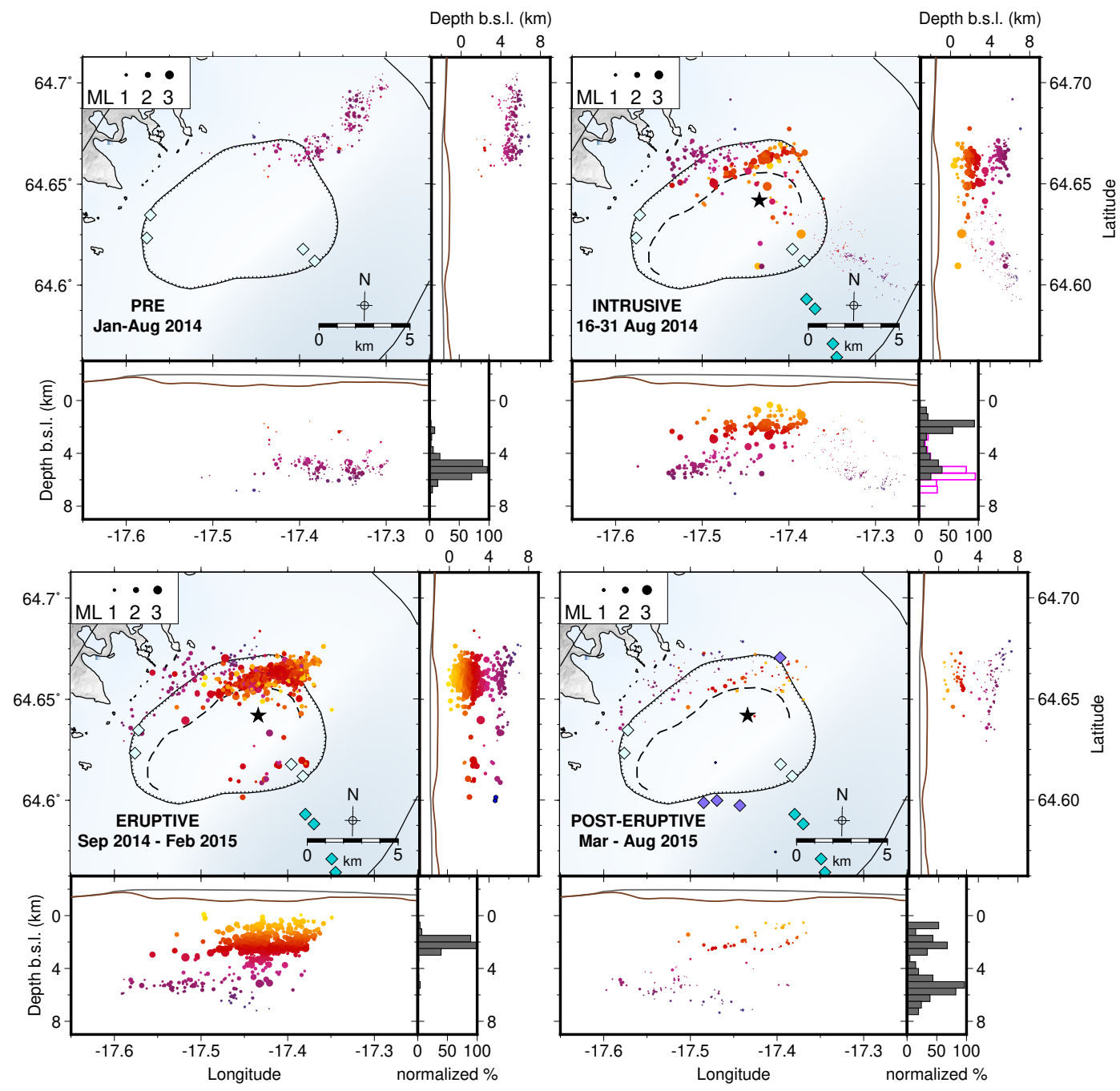

Figure 5. Map view and cross-sections for Bárðarbunga caldera activity 1 January 2014 to 16 August 2015 with each period plotted separately in map and depth view (with depth histogram). Events are color-coded by depth and symbol size represents relative magnitude (note $\mathrm{M}_{L}$ saturates at $\sim 3.5$ ). Diamonds are ice cauldrons color-coded by formation year: white formed before 2014, turquoise formed in 2014, purple in 2015 . The black star represents the center of subsidence [Gudmundsson et al., 2016]. The black dashed line is digitized from Gudmundsson et al. [2016] and represents a possible inner caldera wall constrained using InSAR observations acquired between 17-18 September 2014. In depth cross-sections the glacier surface is grey and caldera bedrock topography in brown (cross-sections) [Björnsson and Einarsson, 1990]. In histograms: dark grey and pink bins show the depth distribution of caldera earthquakes and dike events respectively. 
caldera rim, but again at 4-7 $\mathrm{km}$ depth b.s.l. with $\mathrm{M}_{L}$ 0.6-2.1. The seismicity on the south-eastern side of the caldera, both close to the dike exit and around the geological caldera ring-fault structure, is more active during the eruption than during the intrusive period. The events on the southern side are at 1-6 km depth b.s.l., indicating that the fault is somewhat deeper in the south-eastern part of the caldera than at the northern side. The majority of the caldera seismicity occurred during the first four months of the eruption (Figures 4 and S8), with collapse of the caldera. The eruption was abating from late January 2015 and seismicity decreased 1-2 weeks before the end of the eruption, when the $\mathbf{M}_{w}>4$ events stopped and the cumulative moment plateaued (Figure 4). After the eruption, smaller events can be detected due to the decreased $\mathrm{M}_{c}$ (from 0.9 to 0.3 , Table S5). Post-eruptive activity is characterized by considerably smaller events, with $\mathrm{M}_{L} 0.3-1.7$, exclusively on the northern side of the caldera, scattered over the previously active area at 0-7.5 km depth b.s.l. (Figure 5, lower-right panel).

The depth distribution of the caldera earthquakes during the intrusive and eruptive periods is mostly shallower than during the pre-intrusive and post-eruptive periods, confined to depths of $0-4 \mathrm{~km}$ b.s.l. and mainly occurring on an inner caldera ring-fault structure (Figure 5). Throughout the study period the seismicity extends no deeper than $\sim 7.5 \mathrm{~km}$ b.s.l. (Figure 5), and no deeper than $4.5 \mathrm{~km}$ b.s.l. on the inner ring-fault structure. These observations constrain the seismogenic thickness of the crust under the central part of Bárðarbunga caldera. After the end of the eruption, two very small events occurred deeper than $19 \mathrm{~km}$ under the caldera (black dots, lower right panel Figure 5), which could indicate magma rising at depth.

During the caldera collapse (the intrusive and eruptive periods), seismicity rates and moment release were consistently higher on the northern side of the caldera than on the southern side (Figures 4, 5 and S8). The moment release observed on the northern side of the caldera (grey and purple lines, Figure 4b), is an order of magnitude larger than on the southern side. This is not due to the network geometry, as the lower rate of seismicity at the southern side is seen across all magnitude ranges (both in the initial and refined locations).

The total seismic moment release in the caldera during the rifting event is $4.6 \times 10^{18}$ $\mathrm{Nm}$, which is the same order of magnitude as for the dike during the intrusive period $\left(1.8 \times 10^{17} \mathrm{Nm}\right)$. Gudmundsson et al. [2016] calculate the geodetic moment to be $4 \times 10^{19}$ 
to $4 \times 10^{20} \mathrm{Nm}$, assuming a ring fault stretching from the surface to $12-\mathrm{km}$ depth, $60 \mathrm{~m}$ of slip, and a shear modulus ranging from 2 to $20 \mathrm{GPa}$. It is therefore likely that most of the observed caldera collapse/deformation is aseismic, as the observed seismic moment is at most $10 \%$ of the geodetic moment.

\subsubsection{Caldera rim geometry and earthquake source mechanisms}

During the pre-intrusive period, the earthquake source mechanisms north-east of the caldera show normal faulting mechanisms striking between $015-045^{\circ}$, parallel to the inferred rift fabric in this part of the fissure swarm (yellow, Figure 6a). This is distinctly different from the focal mechanisms of caldera earthquakes during the intrusive and eruptive periods, which are dominated by normal faulting sub-parallel with the caldera rim (turquoise and orange, respectively, Figure 6). The deeper north-western caldera earthquakes have variable FPSs and do not exhibit a clear trend.

At the northern side of the caldera we take the steeply dipping nodal plane striking sub-parallel to the caldera rim to be the fault plane (Figure 6a), as opposed to the shallowly-dipping plane. This is consistent with the requirement from geodetic observations for the inner caldera ring-fault to be steeply dipping [Gudmundsson et al., 2016], and gives consistently oriented slip vectors showing steep downwards movement to the south or southwest. This requires the inner caldera ring fault to be inward-dipping.

Individual fault plane solutions are consistent with this conclusion, showing normal faulting on planes dipping south (Figures 6, S9), with an average inwards dip of $60 \pm 9^{\circ}$ for the intrusive and eruptive periods. The observed variability in the strike of these normal faults likely indicates multiple faults failing, rather than a single coherent ring fault. This is consistent with the distribution of hypocenters in cross section (Figures S10-S11). It would therefore be an oversimplification to fit a linear regression through the seismicity as viewed in cross section (for more detailed discussion see section 4.2.3). The similarity of the earthquake hypocenters and fault plane solutions throughout the caldera collapse indicates that the inward dipping faults must be present from the beginning, and do not evolve from outward dipping faults (for monthly seismicity evolution see Figure S10).

The source mechanisms for earthquakes along the south side of the caldera are less well characterized, due to a smaller number of events. They show more complexity, with varied source mechanisms and strikes, particularly during the intrusive period (turquoise, 


\section{a North side}

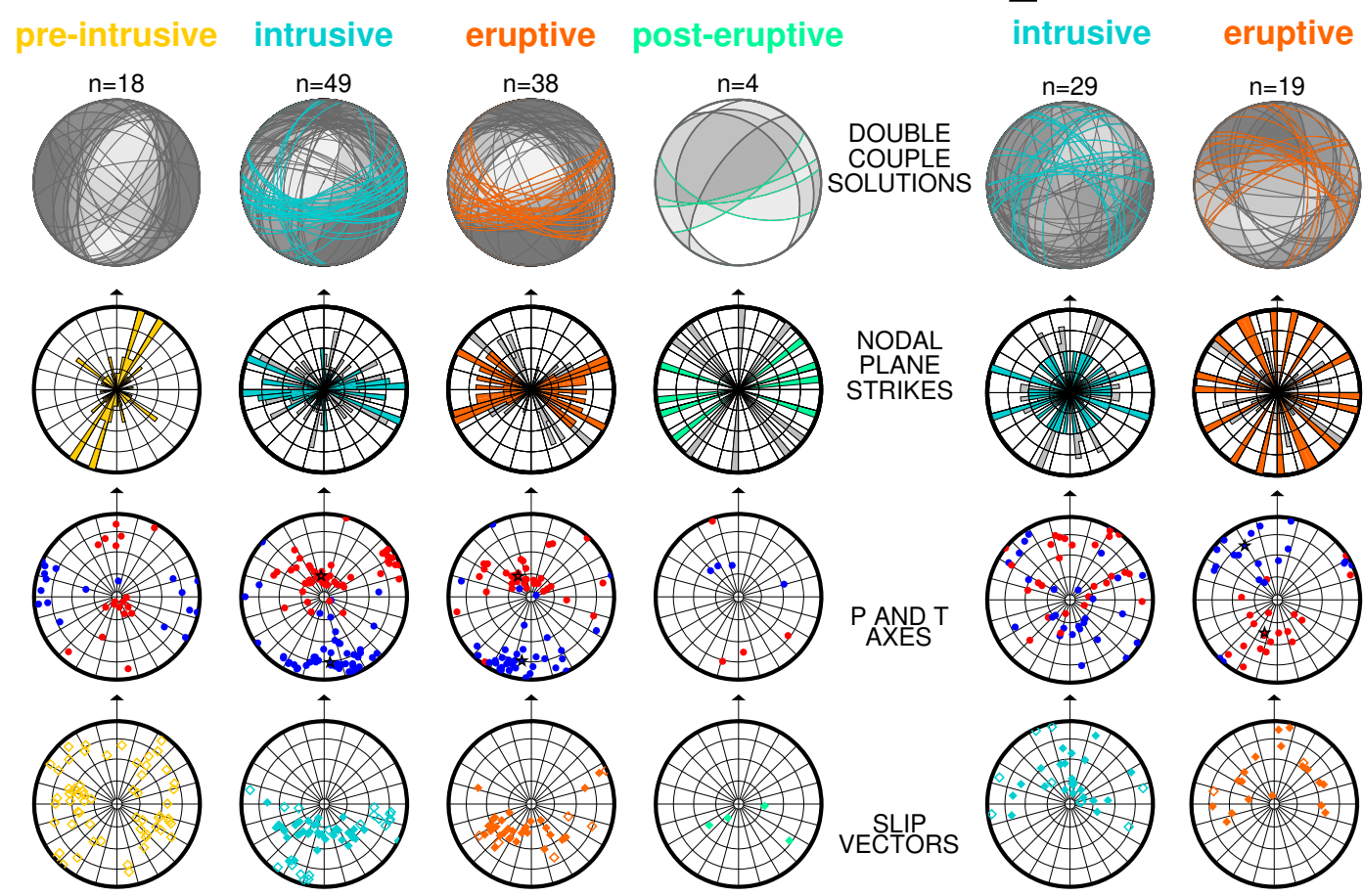

Figure 6. Comparison of the double-couple (DC) moment tensor solutions for the Bárðarbunga caldera events, throughout the study perio for the (a) the northern side and (b) the southern side. Events are split into north and south by $64.63^{\circ} \mathrm{N}$. For each column, panels from top to bottom show: DC solutions (plane interpreted to be the fault plane is color-coded); nodal plane strikes; $\mathrm{P}$ and $\mathrm{T}$ axes (in red and blue respectively), average $\mathrm{P}$ and $\mathrm{T}$ axes shown as stars; slip vectors, shown by filled diamonds where the fault plane is interpreted, and with both possible slip vectors shown by open diamonds where it is not. 
Figure $6 b$ ). This is likely to be due to the interplay between the intrusion of the dike as it leaves the caldera and the onset of caldera collapse. However, during the eruptive period, a more consistent pattern emerges, with normal faults on the southern side of the caldera dipping steeply to the north most common (orange, Figure 6b). This again implies inwarddipping faulting.

Figure 7 shows all the caldera activity during the study period (1 January 2014-16 August 2015), with average FPSs for the northern and southern caldera during the eruptive period, and black arrows showing average slip vectors. The cross-sections (Figures 7b, c) clearly demonstrate the inward movement on the northern and southern caldera faults.

\subsubsection{An indication of magma reservoir recharge?}

During the post-eruptive period steep thrust faulting source mechanisms are observed in the north-eastern corner of the caldera, where normal faulting was observed throughout the collapse (green in Figure 6a and Figures S12-S13). Despite the small sample size, the reversal in the distribution of P- and T-axes clearly demonstrates a polarity reversal in agreement with reports by Jónsdóttir et al. [2017] and Rodriguez-Cardozo et al. [2017]. These events, recorded between 9 July and 16 August 2015, indicate re-inflation of the volcano [Grapenthin et al., 2018], possibly due to recharge of the magma reservoir, or due to viscoelastic response [Li et al., 2019].

\section{Discussion}

\subsection{Dike seismicity}

\subsubsection{A highly segmented dike intrusion}

Field observations of segmented fissures and fractures with en-echelon stepping have been commonly observed within Icelandic rift segments over a range of scales [e.g. Nakamura, 1970; Einarsson, 2008; Hjartardóttir et al., 2012; Hjartardóttir et al., 2015a]. We observe small and large scale en-echelon stepping of the dike seismicity, corresponding with the episodic nature of the dike propagation. This may arise from the dike being emplaced approximately $10^{\circ}$ obliquely to the regional extension axis, therefore requiring a component of shear motion parallel to the dike alongside its opening to achieve the regional (tectonic spreading) direction. 

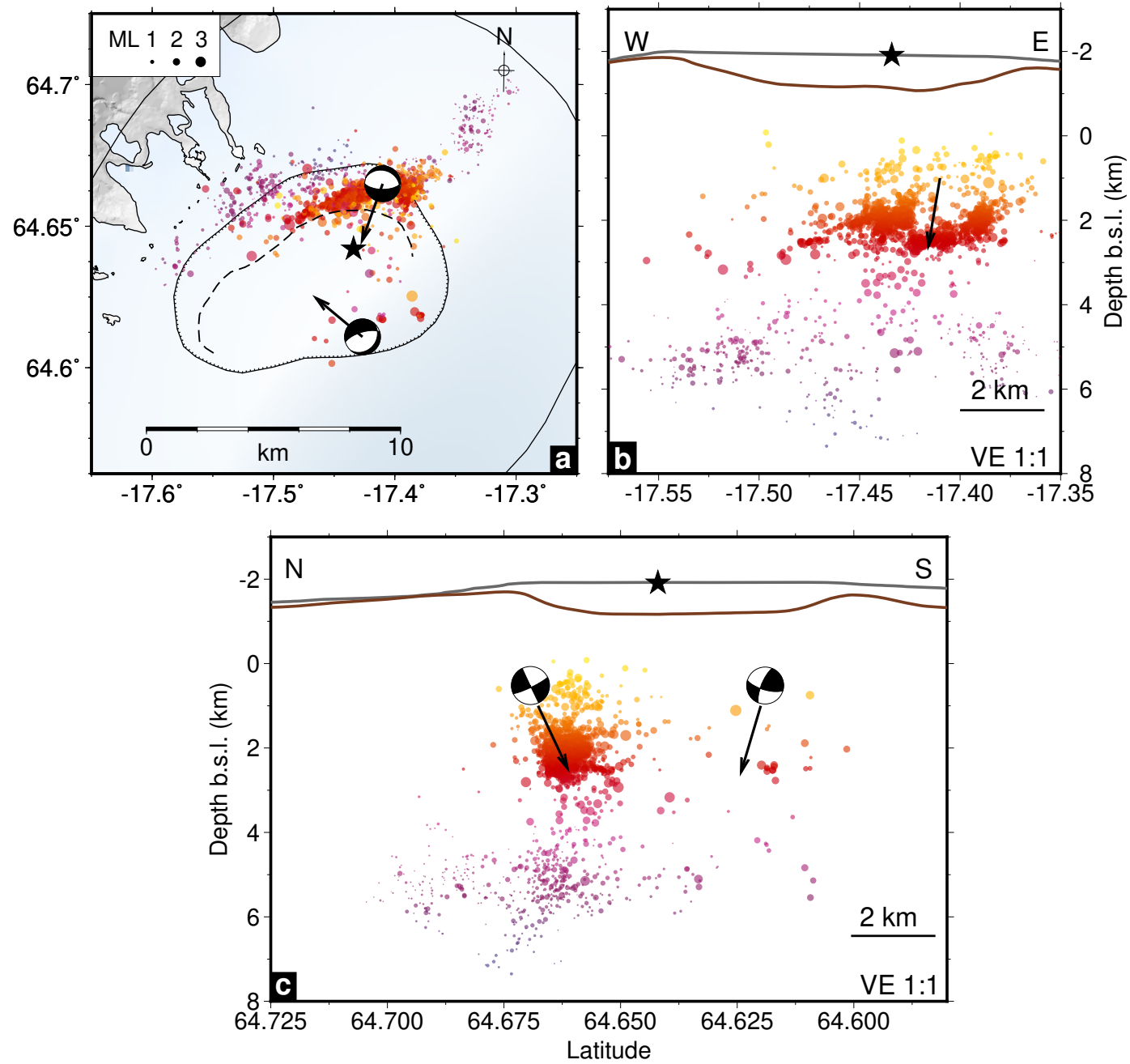

Figure 7. a) Map view of all refined caldera earthquake locations during the study period, 1 January 2014-16 August 2015. Earthquakes are color-coded by depth, with magnitude given by symbol size (note $\mathrm{M}_{L}$ saturates at $\sim 3.5$ ). Black star is the center of subsidence and black dashed line is the inner caldera rim defined by InSAR [Gudmundsson et al., 2016]. Average FPSs for the northern and southern caldera during the eruptive period are shown in a) with black arrows showing average slip vectors, b) longitude versus depth for the northern side shows a westward dipping trend, black arrow is the average slip vector. c) latitude versus depth with average slip vectors shown in black. On cross-sections: glacier topography shown in light blue and caldera surface bedrock with black line [Björnsson and Einarsson, 1990]. 
Precise geodetic measurements (InSAR, LiDAR, UAV photogrammetry and surface mapping) have been made in the distal $10 \mathrm{~km}$ of the dike where it extends from beneath the ice cap, revealing around $1 \mathrm{~m}$ of left-lateral dike-parallel shear during the intrusion, as well as $\sim 4 \mathrm{~m}$ of opening [Ruch et al., 2016; Muller et al., 2017]. Hjartardóttir et al. [2015b] reported en-echelon surface fractures forming north of the Holuhraun eruptive fissure on 27 August 2014, two days prior to the first eruption and three days after the seismicity reached this area. This marked the beginning of the formation of a $\sim 1 \mathrm{~km}$ wide graben which extends from the eruption site to the southernmost ice cauldron [Rossi et al., 2016], mirroring the step-like path of the seismicity (Figure 3). These studies, amongst others, agree that the 2014 dike (and consequent graben) followed pre-existing structures, eventually erupting through craters formed during the last magmatic rifting episode in this fissure swarm in the 18th century [e.g Sigmundsson et al., 2015; Ágústsdóttir et al., 2016].

\subsubsection{Pre-existing rift fabric controls the orientation of induced seismicity}

Right-lateral strike-slip faulting is observed as the dike propagates to the north-east away from the central volcano (segments 2 and 3, Figure 3), followed by a sudden change to left-lateral strike-slip faulting as the dike turns and propagates in a more northerly direction into the NVZ (segments 4 and 5). Though it causes the left-lateral shear observed along the distal segment of the dike [Ruch et al., 2016], the orientation of the dike relative to the regional extension axis does not change along the dike path, indicating it is not this that causes the switch in mechanism. Instead the abrupt change from right-lateral to left-lateral strike-slip between segments 3 and 4 can be explained by the orientation of the dike opening with respect to the local rift fabric. The local rift fabric has been mapped in the SW and NE ice-free regions of the Bárðarbunga fissure swarm, where it strikes at $\sim 040-045^{\circ}$ and $025^{\circ}$, respectively [Einarsson and Saemundsson, 1987; Hjartardóttir et al., 2012; Hjartardóttir et al., 2015a]. Apart from the more varied (and poorly constrained) source mechanisms in the first dike segment, the dike-induced seismicity consistently strikes within this range, gradually decreasing in strike from $\sim 042^{\circ}$ to $\sim 030^{\circ}$ as the dike propagated north-eastwards (Figure 3, S7). This correlates with the gradual rotation of the rift fabric which is presumed to occur from SW to NE beneath the ice [Einarsson and Saemundsson, 1987], suggesting that this is the primary control on the orientation of the induced seismicity. The change from right-lateral to left-lateral faulting occurs where the dike switches from propagating to the east of the fabric (dike strike $\sim 060^{\circ}$, fabric 040 
$045^{\circ}$ in segments 2 and 3, Figure 3) to propagating to the west of it (dike strike $025^{\circ}$, fabric $\sim 025-040^{\circ}$ in segments 4 and 5). Together with the observations of Woods et al. [2019] this strengthens the argument that the seismicity observed along the dike path did not occur on faults physically connected to the dike. Instead, it occurred on pre-existing faults in the brittle crust near the base of the dike, induced by stresses imparted by the dike opening and the background tectonic loading since the last rifting episode $\sim 200$ years previously. This is of significant importance to the interpretation of dike-induced seismicity worldwide.

\subsubsection{Seismicity is observed only in the most distal dike segment at any one time}

Each dike segment went seismically 'quiet' once a segment was intruded beyond it. Magma pressure reaches its maximum in a given segment after it has stalled and inflated for an extended period, corresponding to the maximum stress being induced on preexisting faults in its vicinity [Heimisson and Segall, 2018]. When the dike next advances, the pressure, and induced stress, drops, and seismicity ceases. Significant increase of pressure beyond this point would be required to induce further seismicity, as much of the preexisting tectonic stress would now have been released, causing these early segments to remain quiet for the remainder of the rifting event.

These observations further indicate that the VT seismicity observed along the BárðarbungaHoluhraun dike was not directly caused by the flow of melt. Dike opening must have been accommodated primarily by aseismic Mode I failure, accounting for the two orders of magnitude difference between the seismic and geodetic moment. Similar dominance of aseismic deformation was observed during the 1975-1984 Krafla and 2005-2010 Dabbahu rifting events [Wright et al., 2012]. During the Bárðarbunga-Holuhraun intrusion, only far less common low-frequency earthquakes and tremor reveal evidence of melt movement [Woods et al., 2018]. In contrast, seismicity during the 2007-2008 Upptyppingar intrusion, also in the NVZ, has been attributed primarily to melt fracture [White et al., 2011]. This may be due to the Upptyppingar dike intrusion involving far smaller opening $(0.2-1 \mathrm{~m})$ and occurring over a more protracted period, making cooling and subsequent brittle failure of melt of greater importance. 


\subsection{Caldera seismicity}

\subsubsection{The relationship between dike and caldera seismicity}

Seismicity indicating collapse of the caldera began during the dike propagation, and was at its most active during the eruption while magma was flowing out of the open system. Seismic activity in the caldera then decreased as the eruption abated and the subsidence rate slowed (Figure 4). This indicates a clear link between a deflating magma reservoir beneath the subsiding Bárðarbunga caldera and the dike propagation and eruption, in agreement with previous studies by Sigmundsson et al. [2015] and Gudmundsson et al. [2016]. Furthermore, geochemical studies suggest that the magma erupted at Holuhraun originates from Bárðarbunga [Halldórsson et al., 2018].

\subsubsection{Caldera subsidence}

Subsidence of the caldera was first observed on 5 September 2014, a week into the eruption, by aircraft radar profiling which showed $16 \mathrm{~m}$ subsidence of the ice surface in the central caldera [Sigmundsson et al., 2015]. Radio-echo soundings in February 2015 showed no evidence for basal ice melting, which, combined with the absence of observed melt-water flooding, confirms subsidence of the caldera floor as the cause of the subsidence [Gudmundsson et al., 2016]. Sigmundsson et al. [2015] suggest that the slow collapse of the caldera floor started between 16 and 24 August. The first synthetic aperture radar (SAR) interferogram acquired during the rifting episode (between 27-28 August) shows symmetrical subsidence of the ice surface with the order of $10 \mathrm{~cm}$ line-of-sight displacement [Riel et al., 2015]. The catalog of caldera seismicity presented in this study shows that the long sequence of $\mathrm{M}_{L}>3$ earthquakes caused by the collapse began on the evening of 20 August 2014 (Figure 3c). This shows that subsidence began no later than four days after the dike exited the caldera, during the 81 hour long stalling of its propagation between segments 3 and 4.

Over the course of the 6 month long eruption, a $65 \mathrm{~m}$ deep asymmetrical subsidence bowl formed on the ice surface above the caldera, over an area of $110 \mathrm{~km}^{2}$. Gudmundsson et al. [2016] calculate the total collapse volume to be $\sim 1.8 \pm 0.2 \mathrm{~km}^{3}$, which is the same within error as the total volume of intruded and erupted magma $\left(1.9 \pm 0.3 \mathrm{~km}^{3}\right)$, strongly indicating that a deflating magma reservoir beneath Bárðarbunga fed the dike intrusion and eruption. This is further supported by the in-phase relationship between the 
exponentially declining caldera subsidence rate and the decrease in lava effusion rate at Holuhraun. This also mirrors the decline we observe in the frequency of large magnitude earthquakes in the caldera, and consequently the gradient of the cumulative seismic moment curve (black line, Figure 4). From early February 2015 the rate of caldera seismicity slowed significantly, signalling the slowing and final termination of the eruption. At the end of the eruption, on 27 February 2015, the seismicity drastically reduced, limited to events $\mathrm{M}_{L}<2$ (Figure 4), correlating with the termination of subsidence [Gudmundsson et al., 2016; Pedersen et al., 2017].

The earthquake depth distribution (shallower on the north side, Figure 7), frequency distribution and cumulative moment release (an order of magnitude greater on the north side, Figure 4) all point to asymmetric caldera collapse. This corresponds to the asymmetric subsidence of the ice surface, with the center of subsidence 1-2 km north-east of the center of the caldera [Riel et al., 2015; Gudmundsson et al., 2016]. Cross-sections through the caldera show a very gradual subsidence gradient towards the southern and western boundaries of the caldera, with significantly steeper gradients on the northern and eastern sides [Gudmundsson et al., 2016]. Analysis of one-day SAR interferograms shows that the ice-surface subsidence on days with $\mathrm{M}_{w}>5$ earthquakes is more asymmetrical than those without large earthquakes [Figures 2 and S2 in Riel et al., 2015]. Excess subsidence, and a steeper subsidence gradient, are observed towards the northern side of the caldera, where the majority of the earthquakes occurred. If these earthquakes are assumed to have occurred along a ring-fault structure, this indicates that the asymmetry of surface subsidence is controlled by variable magnitudes of fault slip around the ring fault. This occurred in conjunction with the deflation of a magma reservoir modeled with a horizontal circular crack, which caused ongoing symmetrical subsidence [Riel et al., 2015].

If the asymmetry is caused by activation of only part of the pre-existing ring-fault structure, it is interesting to consider why this is the case. Off-centred (trapdoor-style) collapse is a relatively common feature of natural calderas, though not so frequently recreated in analogue models [Holohan et al., 2013]. Recent examples include Sierra Negra [Jónsson et al., 2005], Piton de la Fournaise [Massin et al., 2011], and Tendurek volcanos [Bathke et al., 2015]. This phenomenon has been explained by off-centered magma efflux, asymmetric mechanical properties of the crust overlying the magma reservoir (and hence asymmetric development of faulting) or the currently active magma reservoir having different dimensions and/or a different location to that which was active at the time the caldera 
ring faults were first developed. In reality, a combination of these effects is likely to contribute to the observed geometry of natural caldera collapses, and even this would represent a simplification of what is likely to be an extended and complex history of caldera evolution through multiple cycles of magma reservoir inflation and deflation, possibly at multiple locations.

In the case of Bárðarbunga, higher temperatures close to the 1996 and 2014 dike exits may make the south east rim of the caldera weaker, suppressing brittle failure and reducing the importance of ring faulting. This is supported by the presence of at least five ice cauldrons in this region, caused by shallow geothermal activity [Riel et al., 2015; Gudmundsson et al., 2016], compared to just one in the north (Figures 1, and 2). No new ice cauldrons were formed along the aseismic western side of the caldera, where two ice cauldrons, formed in the decade prior to the rifting episode are also present.

The center of subsidence is offset to the northeast, and especially far from the mapped western caldera ring fault, due to the east-west elongated ellipsoidal shape of Bárðarbunga. The origin of the dike-induced seismicity suggests that the magma reservoir extends close to the south-east corner of the caldera. The caldera's shape may indicate that the magma reservoir active when the caldera was initially formed had a similarly elongated aspect ratio, or reflect interaction with pre-existing structures associated with regional extension perpendicular to the rift axis [Acocella et al., 2004]. Alternatively, the caldera may in fact be composed of multiple nested calderas developed over time, as can be seen at Askja and Grímsvötn [e.g. Jóhannesson and Saemundsson, 1998]. If the deflation source is significantly offset to the north-east, the large distance between the high-strain regions adjacent to its boundary and the pre-existing fault may suppress seismicity, as a greater differential stress must be achieved to break new faults than to re-activate existing structures [Hildreth and Fierstein, 2000]. The interpretation that strain at the western margin of the deflating reservoir was dominantly accommodated by elastic flexure instead of faulting is supported by the very gradual slope in ice-surface subsidence to the west (Figure 1 in Gudmundsson et al., [2016]), in contrast to the northeast and southern margins. The off-centered location of the center of subsidence may also have been enhanced by a feedback cycle where a large amount of fault movement close to this region of the reservoir causes more subsidence of this part of the roof of the chamber, forcing more melt out [Jónsson et al., 2005]. Interestingly, during the 1996 Gjálp eruption, seismicity was focussed at the northern and 
western sides of the caldera (Figure S24), perhaps leaving the ring fault in that region less prone to failure in 2014 (for more detailed discussion on Gjálp, see section 4.3.3.).

\subsubsection{Caldera rim geometry}

The seismicity we observe during the 2014-15 Bárðarbunga-Holuhraun rifting event clearly outlines the geodetically-inferred inner caldera rim around the northern edge of the asymmetrical subsidence bowl (Figure 7a). The second largest cluster of earthquakes aligns with the geological caldera rim in the north-west, and there is also significant seismicity along the southern rim of the caldera. This corresponds to the distribution of $\mathrm{M}_{w}$ > 5 events analysed by Riel et al. [2015] and Gudmundsson et al. [2016]. These clusters each show different depth distributions.

Earthquakes at the northwest rim of the caldera are primarily located between 4$7.5 \mathrm{~km}$ b.s.l., and possibly represent activity on an outer caldera fault. However, the observed source mechanisms show no clear trend, making it hard to infer the dominant sense of motion.

In contrast, the seismicity on the inner fault at the north of the caldera is confined to 0-4 km b.s.l., and the source mechanisms consistently show steep inward dipping normal faulting aligned with the strike of the curved caldera rim (Figures 6 and 7). An average of the fault plane solutions (FPSs) from the intrusive and eruptive periods gives a dip of $60 \pm 9^{\circ}$ (Figure 7). We interpret the variability of the fault plane solution strikes as subvertical collapse occurring on multiple blocks each bounded by inward dipping normal faults; a mix between the end-member piecemeal and trapdoor collapse styles. This can be compared to the spectacular collapse of Halema'uma'u caldera during the 2018 eruption of Kilauea. High-resolution real-time surface measurements could be made in Kilauea, not obscured by $\sim 800 \mathrm{~m}$ of ice overlying the caldera floor as is the case in Bárðarbunga. They reveal a similar incremental collapse punctuated by discrete large magnitude seismic events, caused by the piecemeal subsidence of fault-bounded blocks around the caldera rim [Neal et al., 2018].

It would therefore be an oversimplification to fit a linear regression through the earthquake hypocenters as viewed in cross-section. Extensive testing has shown that if a regression analysis is undertaken, the observed dip is highly sensitive to the relocation parameters and velocity model used. In the caldera in particular, 3D velocity variations of 
significant amplitude are likely to occur, not captured by our simple 1D model, leading us to conclude that such fine details of the distribution of relocated hypocenters should not be strongly interpreted. Nevertheless, using our optimised relocation parameters, a crosssection through the seismicity is consistent with faulting on a sub-vertically distributed array of multiple inward-dipping faults, with a slight indication of inward dip (Figures 5,7, S10 and S11). However, we place far more weight on the constraint given by the well constrained, high quality fault plane solutions presented in this study, which clearly show failure on inward dipping planes.

On the south side of the caldera, source mechanisms are more variable and are fewer in number. The complexity may arise due to the interaction between caldera subsidence and intrusion of the first dike segment from this location, or due to the smaller sample size. However, during the eruptive period, normal faults dipping steeply to the north dominate, again suggesting that inward dipping normal faulting is the primary mechanism of collapse, though in this case over a slightly different depth range of 1-6 km b.s.l. (Figure 7).

Despite the many complicating factors of the Bárðarbunga caldera collapse, comparison can be made with the geometries typically observed in analogue and numerical models. In these models, the most common pattern is an inner caldera ring fault with a reverse sense of slip surrounded by an outer ring fault with a normal sense of motion [Acocella, 2007]. In cross-section these two faults gradually increase in dip before meeting at depth to form a sub-vertical dip-slip fault, which extends to the margin of the deflating magma reservoir. The exact geometry of this system has been observed to be affected by the width/depth ratio of the magma reservoir, the cohesiveness of the overlying material, the temporal evolution of the collapse and the presence of pre-existing ring faults [Ruch et al., 2012]. We only observe normal faulting at shallow depths, which differs from these models. It initially appears that the cluster of deeper earthquakes in the northwest of the caldera represent the ring fault switching to an outward dipping reverse fault at depth, similar to the 'bottleneck' observed experimentally by Ruch et al. [2012]. However, the relative location of this secondary grouping of earthquakes is less well constrained than the primary shallow cluster in the northeast, due to the limitations of the clustering approach used by HypoDD [Trugman and Shearer, 2017]. This apparent pattern is also very sensitive to the relocation parameters, and even more so to the azimuth chosen for the cross-section display. We therefore place even less weight on this observation 
than the dip of the primary cluster of hypocenters, and again look to the well-constrained fault plane solutions to reveal the style of faulting in this region. There are fewer reliable solutions owing to the smaller magnitude of these earthquakes, and no clear pattern. We therefore conclude that this is unlikely to represent a coherent thrust fault at depth, and is more likely to be a separate area of seismicity triggered by the deformation caused by the deflation of the magma reservoir. Numerical simulations show that there is significant deviatoric strain expected adjacent to and below the chamber depth [Holohan et al., 2013]; for more detailed discussion see section 4.3.

It is also possible that the western portion of the caldera rim fault which was not activated during the 2014-15 collapse has an outward dip, meaning the caldera overall has a piston-type geometry, but with the piston dipping to the west. This phenomenon has been observed at Tendurek volcano [Bathke et al., 2015]. Detailed source inversion of a M 5.6 earthquake caused by caldera subsidence preceding the 1996 Gjálp eruption suggests it was caused by slip on multiple segments of the ring fault, dipping outwards at the west and inwards or vertical in the east (Fig 8; Fichtner and Tkalčić [2010]). A similar source inversion for the large magnitude CLVD earthquakes in 2014-15 would shed further light on this issue.

Despite the speed, area and amplitude of the subsidence, no large surface crevasses were observed anywhere on the ice surface overlying the caldera [Gudmundsson et al., 2016]. This suggests a down-sag of the caldera floor with piecemeal failure at its northern and southeastern rims rather than downwards movement of a coherent fault-bounded block (piston-type collapse). This supports our interpretation that the deformation is accommodated by failure on an array of inward dipping faults, which together form a ring-shaped collapse structure above the deflating magma reservoir. It is important to note that at most $10 \%$ of the geodetic moment is taken up seismically (Figure 4), agreeing with the findings of Riel et al. [2015] that aseismic deformation is of primary importance. Our results suggest that the seismogenic deformation represents slip on limited portions of an array of faults forming a ring-shaped structure. The aseismic deformation is likely to represent a combination of aseismic slip within the same fault zone and deflation of the magma chamber as magma is evacuated at depth, which can be approximated by a closing crack [Riel et al., 2015]. This, along with breaking and bending of the overlying roof, provides space for the inward dipping collapse. 


\subsubsection{Double-couple versus non-double-couple caldera earthquakes}

The great majority of earthquakes analysed here (90\%) can be explained by doublecouple failure, and do not require a volumetric component (e.g. events shown in Figure S14). Only $10 \%$ of the caldera earthquake source mechanisms require a non-doublecouple component to fit the observed distribution of P-wave polarities (Figure S15, Text S4).

The largest $\left(\mathrm{M}_{w}>5\right)$ caldera earthquakes represent failure of larger faults, or multiple fault segments, that are likely to be significantly curved [Fichtner and Tkalčić, 2010; Riel et al., 2015; Gudmundsson et al., 2016]. This can lead to apparent volumetric components in the moment tensor solution even if they actually occur by double-couple failure. The observation of similar CLVD moment tensors with reversed polarities before and after eruptions in Bárðarbunga since 1973 supports this, or another non-destructive mechanism, to explain these earthquakes. This study focusses on well-constrained fault plane solutions for the intermediate size caldera earthquakes $\left(\mathrm{M}_{L} 1-3\right)$. These events are more likely to give pure-DC moment tensor solutions, as their smaller size means that they represent failure of smaller, quasi-planar blocks within the overall curved fault zone. This potentially explains why we find predominantly double-couple source mechanisms compared to the compensated-linear-vector-dipole (CLVD) solutions reported for the largest earthquakes [Riel et al., 2015]. In both cases sub-vertical P-axes are observed.

Alternatively, the differing styles of focal mechanisms we obtain may be due to the fundamentally different moment tensor inversion techniques employed. We invert P-wave first motion polarity picks, while the moment tensor solutions for the largest caldera events are obtained by fitting low-passed filtered full waveforms observed on stations at regional distances. Both approaches are sensitive to the hypocenter depth, and Riel et al. [2015], Gudmundsson et al. [2016] and the global CMT catalog [Dziewonski et al., 1981; Ekström et al., 2012] all use depths of 10-15 km. As we discuss in detail in section 4.3, these are likely to be a significant overestimate of the depths; we find well-constrained source depths shallower than $4.5 \mathrm{~km}$ b.s.1..

\subsection{Depth of the magma storage region}

If we interpret the base of the seismicity to represent the depth of the brittle-ductile transition, we can infer that the top of the zone of melt accumulation (where it is too hot 
for brittle failure to occur, except at very high strain rates) is below this depth [e.g. Parisio et al., 2019]. At the neighbouring Askja volcano the maximum depth of crustal seismicity shallows from $\sim 8 \mathrm{~km}$ b.s.l. in the fissure swarm to $\sim 5 \mathrm{~km}$ b.s.l. beneath the volcano [Soosalu et al., 2010], where the shallow magma reservoir has been imaged at $\sim 5-7 \mathrm{~km}$ b.s.l. using local earthquake tomography [Greenfield et al., 2016]. Our results for Bárðarbunga are consistent with both this pattern of shallowing seismicity from within the fissure swarm towards the inside of the caldera (with deeper seismicity at it's periphery) and the depth of the brittle-ductile transition.

We have demonstrated that the inner caldera seismicity during the dike propagation and eruption accommodated caldera collapse, consistent with the observed pattern of surface subsidence, on steep inward-dipping normal faults. We therefore might instead interpret the maximum depth of the seismicity as representing the maximum depth extent of the faults activated by the deflation of the magma reservoir; this is the same argument presented by Gudmundsson et al. [2016]. If the base of these faults is close to the roof of the deflating magma reservoir this would also imply that it lies at around 4-6 km b.s.l.

In an analysis of intermediate magnitude $\left(\mathrm{m}_{b} 4.5-5.7\right)$ seismicity at Bárðarbunga between 1973-96 Bjarnason [2014] argues that the centroid depths are shallow, with slip occurring at depths $<5 \mathrm{~km}$ below the surface $(<3 \mathrm{~km}$ b.s.l.). Full waveform moment tensor inversions of the $M>5$ earthquakes which preceded the Gjálp eruption in 1996 find best fitting centroid depths of 3.5-3.9 km below the surface (1.5-1.9 km b.s.1.) [Nettles and Ekström, 1998; Konstantinou et al., 2003; Tkalčić et al., 2009]. This implies that the faults responsible for all seismicity observed within Bárðarbunga caldera since earthquakes were detectable do not extend significantly deeper than $\sim 4 \mathrm{~km}$ b.s.l. ( $6 \mathrm{~km}$ below the surface). It is probable that all these earthquakes have been driven by magma movement into and out of the magma storage region beneath the caldera. The consistently shallow depth of faulting suggests that the shallowest part of the magma storage region, extending to about 4-6 km b.s.l., is of primary importance throughout this time period.

Our seismic observations show that magma storage region cannot be shallower than $4 \mathrm{~km}$ b.s.l., but inferring its depth beneath this is subject to several assumptions. If we assume that the strain rates during the caldera collapse were sufficiently high to generate earthquakes all the way to the depth of the magma reservoir roof, our results would imply it lies at approximately $4-6 \mathrm{~km}$ depth b.s.l.. However, it is possible (particularly in light 
of the fact that only a maximum of $10 \%$ of the geodetic moment is observed seismically), that the faults continue deeper than the brittle-ductile transition but are slipping aseismically, implying a greater depth for the magma storage region. We therefore cannot exclude that it lies somewhere below the brittle-ductile transition at $\sim 6 \mathrm{~km}$ b.s.l.. These constraints from seismic observations are consistent with the geodetic constraints presented by Gudmundsson et al. [2016]. InSAR and GPS data are shown to fit a Mogi-point pressure deflation source under the caldera in the depth range of $\sim 6-10 \mathrm{~km}$ b.s.l.. However, Riel et al. [2015] show that there is a strong trade-off between chamber depth, radius and excess pressure for a more realistic circular crack geometry. Seismicity therefore places a stronger constraint on magma reservoir depth than geodetic measurements.

The geobarometry results presented in Gudmundsson et al. [2016] indicate melt residence at pressures of 3.5-5.5 kbar (12-19 km below the surface, using an average crustal density of $2800 \mathrm{~kg} / \mathrm{m}^{3}$ ). They conclude that the melt is stored at roughly $12 \pm 4 \mathrm{~km}$ beneath the caldera floor $(11 \pm 4 \mathrm{~km}$ b.s.l. $)$, but given that both their $\mathrm{CO}_{2}$ and geodetic estimates are shallower, they regard the shallower end of the estimates as more likely. Their pressures were calculated using a parameterisation of the OPAM barometer shown to overestimate equilibration pressures of a calibration dataset [Hartley et al., 2018] . More recent work by Hartley et al. [2018] indicates that the most probable melt inclusion equilibration pressures lie between $2.5-4.2 \mathrm{kbar}(9-15 \mathrm{~km}$ below the surface, or 7-13 km b.s.1.), with the carrier melt equilibrating at $2.1 \pm 0.7 \mathrm{kbar}, \sim 7.5 \mathrm{~km}$ depth below surface $(5.5 \mathrm{~km}$ b.s.l.). These estimates are consistent with the depth constraints we can place from the seismicity, suggesting equilibration at a depth of $4-8 \mathrm{~km}$ b.s.l., plausibly underlain by a sequence of sills through to the base of the crust $(\sim 35 \mathrm{~km}$ b.s.l. $)$.

To have fed the $1.9 \pm 0.3 \mathrm{~km}^{3}$ Holuhraun intrusion and eruption, the shallow Bárðarbunga reservoir must have contained a significant volume of melt (depending on compressibility). We can therefore make a comparison with the major melt storage region at the neighbouring Askja volcano, imaged by seismic tomography at a similar depth of $\sim 5 \mathrm{~km}$ b.s.l., with multiple deeper sills under the volcano observed down to $20 \mathrm{~km}$ b.s.l. [Greenfield and White, 2015; Greenfield et al., 2016]. At Grímsvötn and Krafla volcanoes the melt regions extend even shallower, with their upper surfaces at $\sim 3 \mathrm{~km}$ b.s.l. [Brandsdóttir et al., 1997; Alfaro et al., 2007]. (Table S6 gives an overview of the depth to magma storage region comparing this study to previous studies). 


\subsubsection{Melt ascent from depth}

The major remaining question is how melt feeds the shallow storage region under Bárðarbunga volcano. In contrast to Askja, we have not observed any deep seismicity (> $7.5 \mathrm{~km}$ b.s.l.) indicative of melt movement in the lower crust under Bárðarbunga caldera, except for two very small events after the eruption at around $19 \mathrm{~km}$ b.s.l.. These hypocenters are well constrained (located on 18 stations) and show that we have the capability to detect earthquakes at mid and lower-crustal depths, adding robustness to our observation that the mid and lower-crust beneath Bárðarbunga caldera is almost entirely aseismic. It is probable that melt rises sub-vertically through this region, residing in a series of staging sills, as suggested by Hartley et al. [2018]. That this occurs aseismically is likely to be due to the consistently high activity of Bárðarbunga, with the development of a mature melt plumbing system weakening the crust due to the pervasive presence of melt and anomalously elevated temperatures. This is consistent with the $0.5 \mathrm{~km} / \mathrm{s}$ lower surface wave velocities observed in the upper crust beneath Bárðarbunga (and other hotspot volcanoes) compared to the rest of Iceland [Green et al., 2017].

Though almost no deep seismicity is detected beneath the caldera, a vertical column of deeper seismicity (8-22 km b.s.1.) $\sim 15 \mathrm{~km}$ south-east of the center of the caldera is observed from 2012 to the present day (small black dots at $20 \mathrm{~km}$ distance show the 2014 15 activity, Figure 8). An apparent pause during the 2014-15 dike intrusion and eruption is probably an artefact of increased noise across the network during this period, preventing the detection of small, deep, emergent earthquakes (for $\mathrm{M}_{L}$ see Table S5, for statistics of deep seismicity see Table S7, for overview of deep seismicity during the study period see Figure S16). Hudson et al. [2017] attribute the persistent seismicity to the movement of melt in the otherwise aseismic ductile region of the crust, with the exsolution of $\mathrm{CO}_{2}$ at crustal depths causing locally elevated magmatic pressures and sufficiently high strain rates to allow brittle failure [e.g. Shelly and Hill, 2011; White et al., 2018].

The deep seismicity cluster is located $<5 \mathrm{~km}$ from the $3.5 \mathrm{~km}$ long aseismic gap between segments 1 and 2 of the dike path, which remained aseismic throughout the entire rifting episode (Figure 2). The presence of melt, or at least locally elevated temperatures related to melt ascent, might weaken this region of the crust, preventing brittle failure even when it was subjected to the large stress changes induced by the propagating dike. The correspondence between the locations of the aseismic gap and deep seismicity therefore 
support the interpretation that it represents a deep melt feeder. This opens the possibility that some melt may have bypassed the caldera to feed the dike intrusion and eruption. The same argument could explain the absence of seismicity beneath four aligned cauldrons formed south of Bárðarbunga during the dike intrusion (Figures 1, 2 and 5). In this region, elevated crustal temperatures or melt remaining from the 1996 Gjálp dike intrusion might prevent brittle failure during a small melt or hydrothermal intrusion.

Laterally offset melt ascent bypassing the main caldera melt reservoir has been observed elsewhere, for example at Kilauea [Vinet and Higgins, 2010], and fits with the complex picture of crustal magmatic systems presented by Cashman et al. [2017]. Microseismic studies around Vatnajökull show that melt supply from depth commonly occurs at several locations within a volcanic system, not just beneath the central volcano (for a review see White et al. [2018]). In particular, persistent deep seismicity is recorded at several locations away from the Askja caldera, suggesting multiple locations of magma ascent [Soosalu et al., 2010; Key et al., 2011a,b; Greenfield and White, 2015].

However, the volume of the caldera collapse at Bárðarbunga $\left(1.8 \pm 0.2 \mathrm{~km}^{3}\right)$ is similar to the combined volume of erupted and intruded magma $\left(1.9 \pm 0.3 \mathrm{~km}^{3}\right)[$ Gudmundsson et al., 2016] making it clear that the deep seismicity outside the caldera represents at most a minor feeder. Petrological analysis suggests that mush horizons along the dike path may have made minor contributions to the macrocryst assemblage of the erupted Holuhraun lava [Hartley et al., 2018]. The depth range of seismicity corresponds well to the range of melt inclusion equilibration pressures they observe, but it is likely that this arises from aseismic transport of the magma through a series of sills directly beneath Bárðarbunga. That seismicity is observed along this deep feeder, but not beneath the caldera perhaps supports the interpretation that it represents only relatively minor melt movement through cooler crust, outside the primary region of melt ascent. The rate of melt movement cannot be directly inferred from the observed seismicity Hudson et al. [2017].

\subsubsection{Differences from previously published models of the 2014-15 Bárðarbunga caldera collapse}

In this section, we highlight the main differences between our interpretation of the seismicity and tectonic structure of the Bárðarbunga caldera and that published by Gud- 
mundsson et al. [2016]. The main features of our model, that the caldera collapsed in response to evacuation of magma from an underlying melt reservoir as it fed the dike intrusion to, and eruption at Holuhraun, are in agreement. But there are some differences in the details of how the caldera collapsed.

The major difference between our findings is in the hypocenter distribution of seismicity within the caldera. Both studies present cross-correlated and relatively relocated earthquake hypocenters. However, as described in the supplementary material of Gudmundsson et al. [2016], the initial hypocenter locations calculated with their approach are then manually shifted southwards by $2-3 \mathrm{~km}$ to match the surface expression of the caldera fault identified by InSAR imaging of a M 5.3 event on 18 September 2014 [Gudmundsson et al., [2016]; sees their Supplementary material page 3 "Relative location of microearthquakes"]. They justify this on the basis of stability tests indicating large uncertainties in event latitudes, particularly along the northern rim, on the length-scale of the shift they apply. They attribute this to heterogeneous (slow) velocities within the caldera not included in their 1D velocity model. We have undertaken extensive testing which shows that network geometry has a stronger effect on the calculated hypocenter locations than the 1D velocity model used (Figures S17-S23).

In contrast, the locations we present here have had no epicentral shift applied. We observe a tight correspondence between the distribution of seismicity and its geodetic expression, while keeping the two results strictly independent (Figure 7), despite also using a 1D velocity model. This remains the case whether we use our preferred seismic velocity model or that used by Gudmundsson et al. [2016] (see Figures S20-S23, Text S5). We suggest that the improvement in locations in our study is due to using data from many more stations, particularly close to the caldera (Figure S1), and from taking into account the elevation of seismic stations, rather than assuming they are all located at a single datum level calculated for each event. Due to the steep topography in this region, there are elevation differences of almost $2 \mathrm{~km}$ between some stations, making topography important to the calculated locations, and particularly to their calculated depth.

Gudmundsson et al. [2016] report earthquakes extending to $12 \mathrm{~km}$ depth below the caldera floor ( 10.8 km b.s.l.) along the north and south sides of the caldera. In contrast, we observe seismicity between $0-4 \mathrm{~km}$ b.s.l. at the north-east of the caldera, and down to $7.5 \mathrm{~km}$ b.s.l. in a separate cluster of seismicity below the north-west caldera rim. We 
are able to distinguish these two clusters of events thanks to the higher resolution of our study. However, even considering all events at the north of the caldera together, we still observe a shallower base to the seismicity than Gudmundsson et al. [2016]. A similar discrepancy is seen in the south, where we find that the seismicity extends only to $\sim 6 \mathrm{~km}$ b.s.1.. The difference in depths is important as it provides constraint on the depth of the deflating shallow magma reservoir beneath the caldera, as discussed in section 4.3.

Despite our better constraint on hypocenter locations on the northern side of the caldera (with average absolute uncertainties of $0.5 \mathrm{~km}$ laterally and $1 \mathrm{~km}$ in depth), testing has shown that the dip of the hypocenter distribution in cross-section is sensitive to the relocation parameters and velocity model used. Based on this, we conclude that the dip based on hypocenter depths should not be strongly interpreted. In contrast, Gudmundsson et al. [2016] use the apparent small outwards dip of the shifted hypocenter distribution they present to conclude that the northern caldera subsides on an outward-dipping ring fault. This apparent outward dip is not statistically significant when the uncertainty of their hypocentral locations is considered $(\sim 2.5 \mathrm{~km})$ and is carried out on a dataset that has been significantly shifted laterally, modifying the take-off angles used in the relative relocation procedure and so casting doubt on their accuracy. Our results show that this regression analysis has also likely included two distinct groups of seismicity; the shallower seismicity close to the possible inner caldera fault, and the deeper seismicity beneath the rim, skewing the result (Figures 5, 7 and S10-S11). Though we don't attach significant weight to the observation, if a regression analysis is carried out on only the shallower inner caldera seismicity, a sub-vertical or slightly inwards dipping plane is obtained (Figures S10-S11). More conclusively, the well-constrained fault plane solutions we present for intermediate size caldera events also clearly support normal faulting, sub-parallel to the caldera rim, on inward dipping faults (Figure 7).

The interpreted location and orientation of the northern caldera ring fault are used by Gudmundsson et al. [2016] in much of their subsequent analysis, most importantly for moment tensor decomposition. They find that decomposition of the CLVD moment tensors of the $\mathrm{M}>5$ caldera earthquakes to isolate the shear (DC) component is not stable with respect to the decomposition approach. Uninformed, 'standard' decomposition produces normal-faulting mechanisms along north-south striking planes, inconsistent with the observed subsidence geometry. Instead, they constrain the decomposition by specifying an east-west striking, northward (outward) dipping fault plane to match the dip of their 
hypocenters. This decomposition produces a reverse-faulting DC component. The necessity to impose a fault plane in this analysis, and the inconsistency of the results produced depending on this, demonstrates that the consistent, well-constrained fault plane solutions presented in our study place more precise and reliable constraints on the fault geometry, consistently showing normal faulting on inward-dipping fault planes.

In summary, our higher resolution dataset indicates caldera collapse along sub-vertical inward-dipping faults along the northern and southern sides of the caldera, with seismicity extending down to $4-6 \mathrm{~km}$ b.s.l. within the caldera and $\sim 7.5 \mathrm{~km}$ b.s.l. at the north-western rim. This indicates the most likely depth of the shallow deflating magma reservoir, consistent with the geodetic constraints presented by Gudmundsson et al. [2016], and the most recent geobarometric studies of the Holuhraun lava [Hartley et al., 2018], and is similar to the depth of the shallow magma reservoir imaged at the neighbouring Askja volcano [Greenfield et al., 2016].

\subsubsection{Gjálp}

As discussed in section 4.2.4, comparisons can be made between the seismicity preceding the 1996 Gjálp eruption and the onset of the 2014 dike intrusion (Figure S24). Two days prior to the 1996 eruption, seismicity was recorded at the northern and western rims of Bárðarbunga caldera, subsequently migrating south and southwest along the caldera rim [Einarsson et al., 1997]. During the day before the eruption the seismicity migrated $\sim 20 \mathrm{~km}$ south towards Grímsvötn. Within the uncertainties of the hypocentral locations at the south side of the caldera (Figure S24), it is possible that the 1996 and 2014 dikes exited the caldera at the same location.

Heimisson et al. [2015] modeled the 1996 and 2014 dike propagation paths, specifying the same starting location, and proposed that the path of the 1996 dike was influenced primarily by deviatoric stresses due to plate motion, while the 2014 dike path was primarily controlled by topography. This suggests that the 1996 dike released the deviatoric stress in the vicinity of the caldera, directing the 2014 dike north-eastwards [Heimisson et al., 2015], and supporting the finding from seismic observations that the 2014 dike may have reused the Gjálp dike exit.

A notable difference between the two events is that the presumed onset of the 1996 dike intrusion was preceded by a large earthquake $(\mathrm{M}>5)$ on the northern rim of the 
caldera, with a high rate of seismicity on the western caldera rim. In 2014, by contrast, $\mathrm{M}_{w}>4$ caldera seismicity was not observed until 4 days after the dike intrusion began, with only minor seismicity at the south-eastern corner of the caldera preceding the dike intrusion, and by only two hours. The western caldera rim was aseismic throughout the 2014 dike intrusion and eruption, opposite to the pre-eruptive Gjálp seismicity.

\section{Conclusions}

The focus of this study is the seismicity associated with the 2014-15 BárðarbungaHoluhraun rifting event, summarized in Figure 8 (VE 1:1 stitched cross-section through the volcano caldera and along the dike path). Detailed analysis reveals the segmentation of the dike and gives insight into the origin and nature of the dike-induced seismicity. Careful examination of earthquakes within Bárðarbunga caldera provides a clearer picture of the mechanism of its collapse.

The 2014 Bárðarbunga-Holuhraun dike initiated at 05:45 on 16 August 2014, 0.5 km inside the south-eastern caldera rim, with seismic activity in the caldera starting just $2 \mathrm{hrs}$ earlier. As the dike propagated along the NE fissure swarm, strike-slip faulting was induced towards the base of the dike (5-7 km b.s.l.) on pre-existing weaknesses in the host rock, with fault plane strikes correlating with gradual rotation of the rift fabric from the southwest to the northeast. The slip sense of faulting is found to have been governed by the orientation of the dike opening with respect to the local rift fabric, rather than the regional extensional direction. This resulted in right-lateral strike-slip faulting as the dike propagated to the north-east in segments 2 and 3 (east of the rift fabric), followed by an abrupt switch to left-lateral strike-slip faulting as the dike propagated in a more northerly direction in segments 4 and 5 (west of the rift fabric). These results highlight the importance of pre-existing structures and stresses to dike induced seismicity.

Collapse of the Bárðarbunga caldera began at the latest four days after the dike exited the caldera, during an 81-hour long stalling in the dike propagation, with increased caldera earthquake rate indicating the start of seismogenic subsidence. Thereafter, the caldera seismicity rate and moment release correlate with the geodetically observed caldera subsidence (in turn correlating with the volume of magma emplaced along and erupted from the dike), although at least $90 \%$ of the deformation occurred aseismically. Following dike emplacement, magma flowed aseismically along the first dike segments. In the 
northernmost dike segment, where dike opening was greatest, seismicity continued at a decaying rate throughout the eruption and post-eruption periods.

Seismicity associated with the caldera collapse occurred primarily on the northern rim at $\sim 0-4 \mathrm{~km}$ b.s.l., delineating an inner caldera fault. This closely follows the surface subsidence pattern observed using InSAR, encircling the center of maximum subsidence. Seismicity was also observed on the south-eastern rim, though to a much lesser extent, indicating an asymmetric collapse. Well constrained earthquake source mechanisms show steep normal faulting $\left(60^{\circ} \pm 9^{\circ}\right)$ on multiple inward dipping faults striking sub-parallel to the caldera rim (with $90 \%$ of the analysed caldera earthquakes fit by double-couple moment tensor solutions). This complex spatial pattern of faulting indicates collapse on an array of faults, rather than on a single ring fault, and may therefore be classified as a piecemeal-trapdoor-style caldera collapse.

The depth of earthquakes places the brittle-ductile transition beneath the caldera at 4-6 km b.s.l., perhaps also constraining the depth of the shallow magma storage region beneath Bárðarbunga. This is consistent with independent constraints from the analysis of geodetic data, all historical large magnitude earthquakes in the caldera and the most recent geobarometry studies. A tomographic study of Bárðarbunga is however required to constrain the precise location and geometry of a shallow magma reservoir, and may also shed light on the deeper structure of the Bárðarbunga magmatic system. Lack of deeper seismicity suggests it is likely to be hot, with perhaps multiple sills or mush zones.

The 2014-15 Bárðarbunga-Holuhraun dike intrusion is an excellent example of lateral dike propagation from a central volcano in the Icelandic crust, with implications for other large basaltic volcanoes. The observed seismicity (Figure 8) delineates earthquakes induced on pre-existing faults by aseismic inflation of the dike, and the coupled deformation of the subsiding caldera as magma was intruded along the dike and erupted at Holuhraun. The seismicity associated with the caldera collapse highlights its complexity, with implications for understanding the structure and deformation of calderas worldwide, and the importance of a dense seismic network and precise and accurate earthquake locations to make robust interpretations. However, the seismicity alone does not tell the whole story; the dike intrusion and caldera collapse were both at least $90 \%$ aseismic. Earthquakes generally map the regions of high stress changes in brittle regions of the crust adjacent to or above the main areas of melt movement at depth. It is therefore important 
to combine these results with constraints from surface deformation studies, petrology and geochemistry to fully understand and model how melt moves through the crust to intrusion or eruption. The 2014-15 Bárðarbunga-Holuhraun rifting event represents a rare opportunity to do so.

\section{Acknowledgments}

Seismometers were borrowed from the Natural Environment Research Council (NERC) SEIS-UK [loans 968 and 1022], with funding from the NERC and the European Community's Seventh Framework Programme [grant 308377, Project FUTUREVOLC], and graduate studentships from the NERC and Shell UK. The Icelandic Meteorological Office (data delivery from IMO seismic database 20151001/01), Chris Bean (University College Dublin), and the British Geological Survey provided additional seismic data. We thank Sveinbjörn Stein $\tilde{A}_{i}$ Âşrsson, Ágúst PórGunnlaugsson, Heidi Soosalu and others who assisted with fieldwork. John Maclennan and Jurgen Neuberg provided constructive comments and we thank Jonathan Smith coding assistance. We thank Páll Einarsson, Joel Ruch and an anonymous reviewer for their valuable comments that greatly improved the manuscript. Hypocenters used in this paper are listed in Data Sets S1-S4. FPS calculated and used in this paper are listed in Data Sets S5-S6. Department of Earth Sciences, Cambridge contribution esc. 4435 .

\section{References}

Acocella, V., Funiciello, R., Marotta, E., Orsi, G. and De Vita, S. (2004). The role of extensional structures on experimental calderas and resurgence. Journal of Volcanology and Geothermal Research, 129(1-3), 199-217. https://doi.org/10.1016/S03770273(03)00240-3

Acocella, V. (2007). Understanding caldera structure and development: An overview of analogue models compared to natural calderas. Earth-Science Reviews, 85(3), 125-160. https://doi.org/10.1016/j.earscirev.2007.08.004

Alfaro, R., Brandsdóttir, B., Rowlands, D. P., White, R. S., \& Gudmundsson, M. T. (2007). Structure of the Grímsvötn central volcano under the Vatnajökull icecap, Iceland. Geophysical Journal International, 168, 863-876. https://doi.org/10.1111/j.1365246x.2006.03238.x 

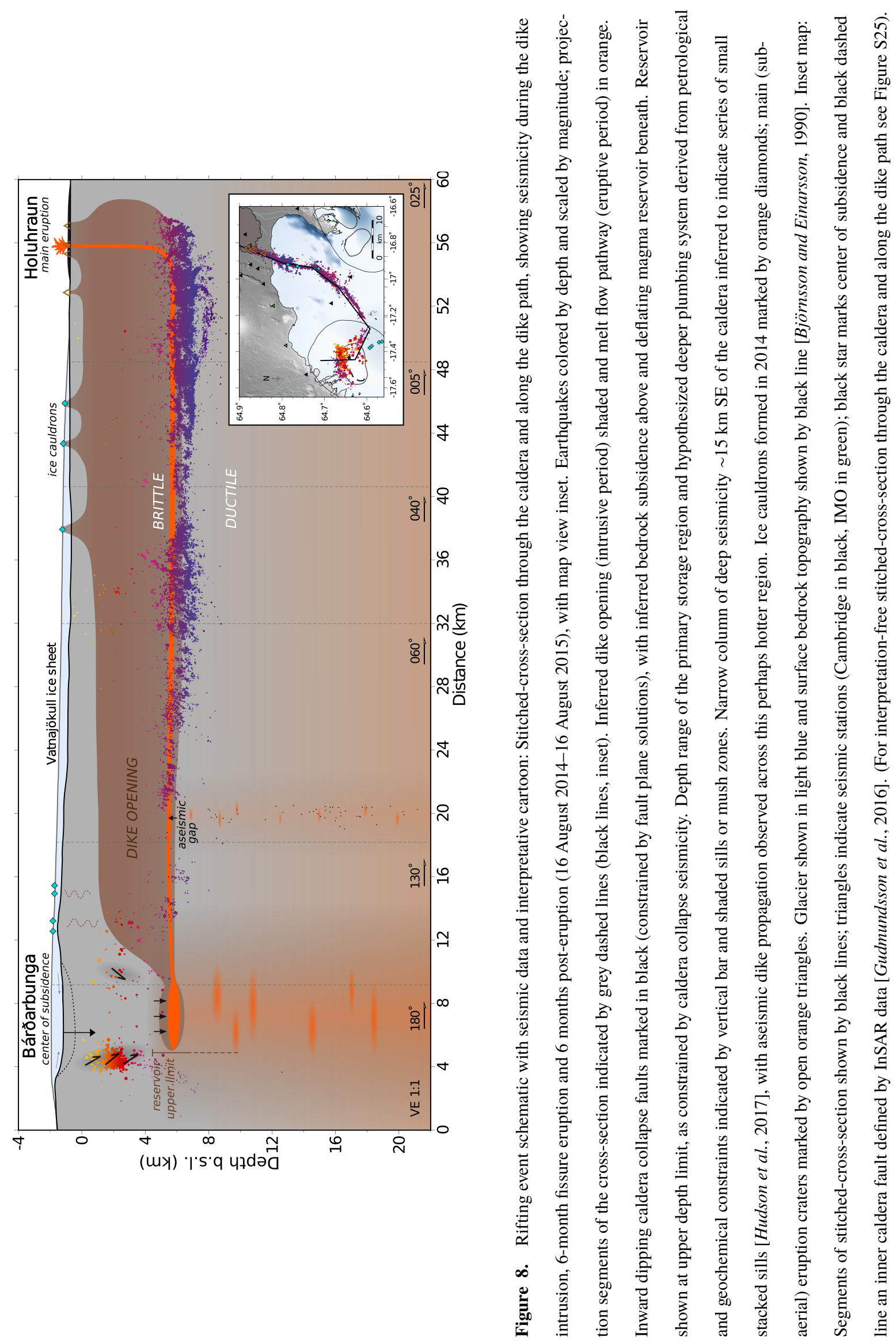
Ágústsdóttir, T., Woods, J., Greenfield, T., Green, R. G., White, R. S., \& Winder, T., et al. (2016). Strike-slip faulting during the 2014 Bárðarbunga-Holuhraun dike intrusion, central Iceland. Geophysical Research Letters, 43, 1495-1503. https://doi.org/10.1002/2013GL058740

Bathke, H., Nikkhoo, M., Holohan, E., \& Walter, T. (2015). Insights into the 3D architecture of an active caldera ring-fault at Tendürek volcano through modeling of geodetic data. Earth and Planetary Science Letters, 422, 157-168. https://doi.org/10.1016/j.eps1.2015.03.041

Battaglia, J., Ferrazzini, V., Staudacher, T., Aki, K., \& Cheminée, J.-L. (2005). Preeruptive migration of earthquakes at the Piton de la Fournaise volcano (Réunion Island.) Geophysical Journal International, 161(2), 549-558. https://doi.org/10.1111/j.1365246x.2005.02606.x

Bjarnason, I. Th. (2014). Earthquake sequence 1973-1996 in Bárðarbunga Volcano: Seismic activity leading up to eruptions in the NW-Vatnajökull area, Jökull, 64, 61-82.

Björnsson, H., \& Einarsson, P. (1990). Volcanoes beneath Vatnajökull, Iceland: Evidence from radio echosounding, earthquakes and jökulhlaups. Jökull, 40, 147-168.

Brandsdóttir, B., \& Pálsson, F. (2014). Historical accounts of 18th century eruptions possibly associated with Bárðarbunga og Grímsvötn. Jökull, 64, 91-106.

Brandsdóttir, B., Menke, W., Einarsson, P., White, R. S., \& Staples R. K., (1997). Färoe-Iceland Ridge Experiment 2. Crustal structure of the Krafla central volcano. Journal of Geophysical Research: Solid Earth, 102(B4), 7867-7886. https://doi.org/10.1029/96JB03799

Branney, M., \& Acocella, V. (2015). Calderas. In H. Sigurdsson, B. Houghton, S. McNutt, H. Rymer, J. Stix (Eds.), The encyclopedia of volcanoes, 299-320, Elsevier.

Cashman, K. V., \& Giordano, G. (2014). Calderas and magma reservoirs. Journal of Volcanology and Geothermal Research, 288, 28-45. https://doi.org/10.1016/j.jvolgeores.2014.09.007

Cashman, K. V., Sparks, R. S. J., \& Blundy, J. D. (2017). Vertically extensive and unstable magmatic systems: A unified view of igneous processes. Science, 355(6331). https://doi.org/10.1126/science.aag3055

Cole, J., Milner, D., \& Spinks, K. (2005). Calderas and caldera structures: a review. Earth-Science Reviews, 69(1), 1-26. https://doi.org/10.1016/j.earscirev.2004.06.004 
Darbyshire, F., Bjarnason, I. Th., White, R. S., \& Flóvenz, Ó. G. (1998), Crustal structure above the Iceland mantle plume imaged by the ICEMELT refraction profile. Geophysical Journal International, 135(3), 1131-1149. https://doi.org/10.1111/j.1365246x.1967.tb06265.x

DeMets, C., Gordon, R. G., \& Argus, D. F. (2010). Geologically current plate motions. Geophysical Journal International, 181(1), 1-80. https://doi.org/10.1111/j.1365246X.2009.04491.x

Drew, J., White, R. S., Tilmann, F., \& Tarasewicz, J. (2013). Coalescence microseismic mapping. Geophysical Journal International, 195, 1773-1785. https://doi.org/10.1093/gji/ggt331

Dziewonski, A. M., Chou, T.-A., \& Woodhouse, J. H. (1981). Determination of earthquake source parameters from waveform data for studies of global and regional seismicity. Journal of Geophysical Research: Solid Earth, 86(B4), 2825-2852, https://doi.org/10.1029/JB086iB04p02825

Einarsson, P., \& Brandsdóttir, B. (1980). Seismological evidence for lateral magma intrusion during the July 1978 deflation of the Krafla volcano in NE-Iceland. Journal of Geophysics, 47, 160-165.

Einarsson, P. (1986). Seismicity along the eastern margin of the North American Plate. In P. R. Vogt, B. E. Tucholke (Eds.), The Geology of North America. The Western North Atlantic Region. (Vol. M, pp. 99-116). Geological Society of America. https://doi.org/10.1130/DNAG-GNA-M

Einarsson, P. (1987). Compilation of earthquake fault plane solutions in the North Atlantic and Arctic Oceans. Earthquake epicenters 1982-1985 and volcanic systems in Iceland. In K. Kasahara (Ed.), Recent plate movements and deformation. Geodynamics Series, (Vol. 20, pp. 47-62). Washington, DC: American Geophysical Union. https://doi.org/10.1029/GD020

Einarsson, P., \& Sæmundsson, K. (1987). Earthquake epicenters 1982-1985 and volcanic systems in Iceland .In. Th. Sigfússon (Ed.), Í hlutarins eðli, Festschrift for Th. Sigurgeirsson (geological map). Menningarsjóður, Reykjavík.

Einarsson, P. (1991). Earthquakes and present-day tectonism in Iceland. Tectonophysics, $189,261-279$.

Einarsson, P., Brandsdóttir, B., Gudmundsson, M. T., Björnsson, H., Grönvold, K., \& Sigmundsson, F. (1997). Center of the Iceland hotspot experiences volcanic unrest. Eos, 
Transactions American Geophysical Union, 78(35), 369-375.

Einarsson, P. (2008). Plate boundaries, rifts and transforms in Iceland. Jökull, 58(12), 3558.

Einarsson, P. (2018). Short-Term Seismic Precursors to Icelandic Eruptions 1973?2014 Frontiers Earth Science, 6(45). https://doi.org/10.3389/feart.2018.00045

Ekström, G. (1994). Anomalous earthquakes on volcano ring-fault structures. Earth and Planetary Science Letters, 128(3-4), 707-712. https://doi.org/10.1016/0012821X(94)90184-8

Ekström, G., Nettles, M., \& Dziewoński A. (2012). The global CMT project 2004-2010: Centroid-moment tensors for 13,017 earthquakes. Physics of the Earth and Planetary Interiors, 200, 1-9. https://doi.org/10.1016/j.pepi.2012.04.002

Got, J-L, Fréchet, J. \& Klein, F. W. (1994). Deep fault plane geometry inferred from multiplet relative relocation beneath the south flank of Kilauea. Journal of Geophysical Research: Solid Earth, 99(B8). https://doi.org/10.1029/94JB00577

Fichtner, A., and Tkalčić, H. (2010). Insights into the kinematics of a volcanic caldera drop: Probabilistic finite-source inversion of the 1996 Bárdarbunga, Iceland, earthquake. Earth and Planetary Science Letters, 297(3-4), 607-615.

Gebrande, H., Miller, H. \& Einarsson, P. (1980). Seismic structure of Iceland along the RRISP profile 1. Journal of Geophysics, 47, 239-249.

Gíslason, S. R.,Stefánsdóttir, G., Pfeffer, M. A., Barsotti, S., Jóhannesson, Th., Galeczka I., et al. (2015). Environmental pressure from the 2014-15 eruption of Bárðarbunga volcano, Iceland. Geochemical Perspectives Letters, 2, 84-93. http://doi.org/10.7185/geochemlet.1509

Got, J-L, Fréchet, J. \& Klein, F. W. (1994). Deep fault plane geometry inferred from multiplet relative relocation beneath the south flank of Kilauea. Journal of Geophysical Research: Solid Earth, 99(B8). https://doi.org/10.1029/94JB00577

Grandin, R., Jacques, E., Nercessian, A., Ayele, A., Doubre, C., \& Socquet, A. et al. (2011). Seismicity during lateral dike propagation: Insights from new data in the recent Manda Hararo-Dabbahu rifting episode (Afar, Ethiopia). Geochemistry GeophysicsGeosystems, 12(4), Q0AB08, 1-24. https://doi.org/10.1029/2010GC003434

Grapenthin, R., Li, S., Ofeigsson, B., Sigmundsson, F., Drouin, V., Hreinsdottir, S., Parks, M. \& Fridriksdottir, H. (2018). Post-eruptive Deformation after the 2014-2015 Bárðarbunga Dike Instrusion and Rifting Event, Iceland. in EGU General Assembly Conference 
Abstracts (Vol. 20, p. 15632), 20,p. 15632 .

Green, R. G., Greenfield, T., \& White, R. S. (2015). Triggered earthquakes suppressed by an evolving stress shadow from a propagating dyke. Nature Geoscience, 8(8), 629-632. http://doi.org/10.1038/ngeo2491

Green, R. G., Priestley, K. F., \& White, R. S. (2017). Ambient noise tomography reveals upper crustal structure of Icelandic rifts. Earth and Planetary Science Letters, 466, 20 31. http://doi.org/10.1016/j.eps1.2017.02.039

Greenfield, T., \& White, R. S. (2015). Building Icelandic igneous crust by repeated melt injections. Journal of Geophysical Research: Solid Earth, 120(11), 7771-7788. http://doi.org/10.1002/2015JB012009

Greenfield, T., White, R. S., \& Roecker, S. (2016). The magmatic plumbing system of the Askja central volcano, Iceland, as imaged by seismic tomography. Journal of Geophysical Research: Solid Earth, 121(10), 6989-7703. http://doi.org/10.1002/2016JB013163

Greenfield, T., White, R. S., \& Winder, T., Ágústsdóttir, T. (2018). Seismicity of the Askja and Bardarbunga volcanic systems of Iceland, 2009-2015. Journal of Volcanology and Geothermal Research, https://doi.org/10.1016/j.jvolgeores.2018.08.010

Gudmundsson, M. T., \& Högnadóttir, T. (2007). Volcanic systems and calderas in the Vatnajökull region, central Iceland: Constraints on crustal structure from gravity data. Journal of Geodynamics, 43(1), 153-169. http://doi.org/10.1016/j.jog.2006.09.015

Gudmundsson, M. T., Jónsdóttir, K., Hooper, A., Holohan, E. P., Halldórsson, S. A., Ófeigsson, B. et al. (2016), Gradual caldera collapse at Bárdarbunga volcano, Iceland, regulated by lateral magma outflow. Science, 353(6296), 262-271. http://doi.org/10.1126/science.aaf8988

Gudmundsson, Ó., Brandsdóttir, B., Menke, W., \& Sigvaldason, G. E. (1994). The crustal magma chamber of the Katla volcano in south Iceland revealed by 2D seismic undershooting. Geophysical Journal International, 119(1), 277-296. https://doi.org/10.1111/j.1365-246X.1994.tb00928.x

Guttormsson, H. (2014). Grímsvatnajökull, ancient routes north of Vatnajökull and the older Holuhraun. Jökull, 64, 107-124.

Halldórsson, S. A., \& Bali, E., \& Hartley, M. E., \& Neave, D. A. \& Peate, D. W., \& Guðfinnsson, G. H., \& Bindeman, I., \& Whitehouse, M. J., \& Riishuus, M. S., \& Pedersen, G. B. M., \& Jakobsson, S., \& Askew, R., \& Gallagher, C. R., \& Guðmundsdóttir, E. R., \& Gudnason, J., \& Moreland, W. M., \& Óskarsson, B. V. \& Nikkola, P., \& 
Reynolds, H. I., \& Schmith, J., \& Thordarson, T. (2018). Petrology and geochemistry of the 2014-2015 Holuhraun eruption, central Iceland: compositional and mineralogical characteristics, temporal variability and magma storage Contributions to Mineralogy and Petrology, 173(64). http://doi.org/10.1007/s00410-018-1487-9

Hartley, M. E., \& Thordarson, T. (2013). The 1874-1876 volcano-tectonic episode at Askja, North Iceland: Lateral flow revisited. Geochemistry, Geophysics, Geosystems, 14(7), 2286-2309. http://doi.org/10.1002/ggge.20151

Hartley, M. E., Bali, E., Maclennan, J., Neave, D. A., \& Halldórsson S. A. (2018).

Melt inclusion constraints on petrogenesis of the 2014-2015 Holuhraun eruption, Iceland. Contributions to Mineralogy and Petrology, 173(2), 10-33. http://doi.org/10.1007/s00410-017-1435-0

Heimisson, E. R., Hooper, A., \& Sigmundsson, F. (2015). Forecasting the path of a laterally propagating dike. Journal of Geophysical Research: Solid Earth, 8774-8792. http://doi.org/10.1002/2015JB012402

Heimisson, E. R., \& Segall, P. (2018). Fully consistent modeling of deformation and dike induced seismicity: Application to the 2014 Bardarbunga dike, Iceland. In AGU Fall Meeting Abstracts, V23G-0145.

Hildreth, W. and Fierstein, J. (2000). Katmai volcanic cluster and the great eruption of 1912. Geological Society of America Bulletin, 112(10), 1594-1620. https://doi.org/10.1130/0016-7606(2000)112<1594:KVCATG>2.0.CO;2

Hjartardóttir, Á. R., \& Einarsson, P. (2012). The Kverkfjöll fissure swarm and the eastern boundary of the Northern Volcanic Rift Zone, Iceland. Bulletin of volcanology, 74(1), 143-162. https://doi.org/10.1007/s00445-011-0496-6

Hjartardóttir, Á. R., Einarsson, P., Magnúsdóttir, S., Björnsdóttir, P., \& Brandsdóttir, B. (2015). Fracture systems of the Northern Volcanic Rift Zone, Iceland: an onshore part of the Mid-Atlantic plate boundary. Geological Society, London, Special Publications, 420, 297-314. https://doi.org/10.1144/SP420.1

Hjartardóttir, Á. R., Einarsson, P., Gudmundsson, M. T., \& Högnadóttir, T. (2015). Fracture movements and graben subsidence during the 2014 Bárðarbunga dike intrusion in Iceland. Journal of Volcanology and Geothermal Research, 310, 242-252. https://doi.org/10.1016/j.jvolgeoters.2015.12.002

Holohan, E. P., Walter, T. R., Schöpfer, M. P., Walsh, J. J., Wyk de Vries, B., \& Troll, V. R. (2013). Origins of oblique-slip faulting during caldera subsidence. Journal of Geo- 
physical Research: Solid Earth. 118(4), 1778-1794. https://doi.org/10.1002/jgrb.50057

Hudson, T. S., White, R. S., Brisbourne, A., Greenfield, T., Ágústsdóttir, T., \& Green, R. G. (2017). Deep crustal melt plumbing of Bárðarbunga volcano Iceland. Geophysical Research Letters, 8785-8794. https://doi.org/10.1002/2017GL074749

Li, S., Sigmundsson, F., Drouin, V., Ofeigsson, B. G., Parks, M. M., Grapenthin, R., Geirsson, H. \& Hooper, A. (2019) Ground deformation following a caldera collapse: Contributions of viscoelastic response and magma inflow to 2015-2018 deformation field around Bárðarbunga, Iceland. In EGU General Assembly Conference Abstracts 21, 11376.

Jakobsdóttir, S. S. (2008). Seismicity in Iceland: 1994-2007. Jökull, 58, 75-100.

Jenkins, J., Maclennan, J., Green, R. G., Cottaar, S., Deuss, A. F., \& White R. S. (2018). Crustal formation on a spreading ridge above a mantle plume: receiver function imaging of the Icelandic crust Journal of Geophysical Research: Solid Earth, 123(6), 5190-5208. https://doi.org/10.1029/2017JB015121

Jóhannesson, H., \& Saemundsson, K. (1998). Jarðfræðikort af Íslandi. Höggun (Geological Map of Iceland. Tectonics). Náttúrufraeðistofnun Íslands (Icelandic Institute of Natural History), Reykjavík.

Jónsdóttir, K., Hooper, A., Jónasson, K., Vogfjörð, K., Gudmundsson, M. T., Hjörleifsdóttir, V., et al. (2017). Bárðarbunga volcano-post-eruption trends following the Holuhraun eruption in 2014-2015. EGU General Assembly Conference Abstracts, vol. 19, p. 12535.

Jónsson, S., Zebker, H. \& Amelung, F. (2005). On trapdoor faulting at Sierra Negra volcano, Galápagos. Journal of Volcanology and Geothermal Research, 144,1, 59-71.

Key, J., White, R. S., Soosalu, H. \& Jakobsdóttir, S. S. (2011a). Multiple melt injection along a spreading segment at Askja, Iceland. Geophysical Research Letters, 38(5), L05301, 1-5. https://doi.org/10.1029/2010GL046264

Key, J., White, R. S., Soosalu, H. \& Jakobsdóttir, S. S. (2011b). Correction to "Multiple melt injection along a spreading segment at Askja, Iceland". Geophysical Research Letters, 38(10), L10308, 1. https://doi.org/10.1029/2011GL047491

Konstantinou, K. I., Kao, H., Lin, C.-H., \& Liang, W.-T. (2003). Analysis of broad-band regional waveforms of the 1996 September 29 earthquake at Bárdarbunga volcano, central Iceland: investigation of the magma injection hypothesis. Geophysical Journal International, 154(1), 134-145. https://doi.org/10.1046/j.1365-246X.2003.01932.x 
Larsen, G., \& Gudmundsson, M. T. (2015). Catalogue of Icelandic Volcanoes - Bárðarbunga volcanic system. Available from: http://futurevolc.vedur.is.

Larsen, G., Guðmundsson, M. T., Einarsson, P., \& Thordarson, T. (2013). In. J. Sólnes, B. Bessason and F. Sigmundsson (Eds.), Náttúruvá á Íslandi - Eldgos og jarðskjálftar (Natural Hazards in Iceland - Eruptions and Earthquakes (in Icelandic). 253-261, Viðlagatrygging Íslands/Háskólaútgáfan, Reykjavík.

Lipman, P. W. (1997). Subsidence of ash-flow calderas: relation to caldera size and magma-chamber geometry. Bulletin of volcanology, 59(3), 198-218. https://doi.org/10.1007/s004450050186

Lomax, A., Virieux, J., Volant, P., \& Berge-Thierry, C. (2000). Probabilistic Earthquake Location in 3D and Layered Models. In C. Thurber and N. Rabinowitz (Eds.), Advances in seismic event location. Modern approaches in geophysics (Vol. 18, pp. 101-134). Springer, Netherlands. https://doi.org/10.1007/978-94-015-9536-0_5

Martens, H. R., White, R. S., Key, J., Drew, J., Soosalu, H., \& Jakobsdóttir, S. S. (2010). Dense seismic network provides new insight into the 2007 Upptyppingar dyke intrusion. Jökull, 60, 47-66.

Massin, F., Ferrazzini, V., Bachèlery, P., Nercessian, A., Duputel, Z., \& Staudacher, T. (2011). Structures and evolution of the plumbing system of Piton de la Fournaise volcano inferred from clustering of 2007 eruptive cycle seismicity. Journal of Volcanology and Geothermal Research, 202(1), 96-106. https://doi.org/10.1016/j.jvolgeores.2011.01.008

Mitchell, M. A., White, R. S., Roecker, S., \& Greenfield, T. (2013). Tomographic image of melt storage beneath Askja Volcano, Iceland using local microseismicity. Geophysical Research Letters, 40(19), 5040-5046. https://doi.org/10.1002/grl.50899

Muller, D., Walter, T. R., Schöpa, A., Witt ,T., Steinke, B., Gudmundsson, M. T., Durig, T. (2017). Modeling from TLS and UAV Campaign Reveals Structural Complexity at the 2014/2015 Holuhraun Eruption Site, Iceland Frontiers in Earth Science, 5(59). https://doi.org/10.3389/feart.2017.00059

Nakamura, K. (1970). En echelon features of Icelandic ground fissures. Acta Naturalia Islandica, 2, 3-15.

Neal, C. A., et al. (2019). The 2018 rift eruption and summit collapse of Kilauea Volcano. Science, eaav7046. 
Nettles, M., \& Ekström, G. (1998). Faulting mechanism of anomalous earthquakes near Bárdarbunga Volcano, Iceland. Journal of Geophysical Research: Solid Earth, 103(B8), 17,973-17,983. https://doi.org/10.1029/98JB01392

Newhall, C. G., \& Dzurisin, D. (1988). Historical unrest at large calderas of the world. U.S. G.P.O., Bulletin 1855, 2 v. 1108, maps, U.S. Department of the Interior.

Óladóttir, B. A., Sigmarsson, O., Larsen, G., \& Devidal, J.-L. (2011). Provenance of basaltic tephra from Vatnajökull subglacial volcanoes, Iceland, as determined by major- and trace-element analyses. The Holocene, 21(7), 1037-1048. https://doi.org/10.1177/0959683611400456

Pálmason, G. (1971). Crustal structure of Iceland from explosion seismology. Societas Scientiarum Islandica, pp. 187. Reykjavík, Iceland.

Parisio, F., Vinciguerra, S., Kolditz, O. and Nagel, T. (2019). The brittle-ductile transition in active volcanoes. Scientific reports, 9(1), 143. https://doi.org/10.1038/s41598-018$36505-\mathrm{x}$

Pedersen, G., Höskuldsson, A., Dürig, T., Thordarson, T., Jónsdóttir, I., Riishuus, M., et al. (2017). Lava field evolution and emplacement dynamics of the 2014-2015 basaltic fissure eruption at Holuhraun, Iceland. Journal of Volcanology and Geothermal Research, 155-169. https://doi.org/10.1016/j.jvolgeores.2017.02.027

Pugh, D. J., White, R. S., \& Christie, P. A. F. (2016). A bayesian method for microseismic source inversion. Geophysical Journal International, 206(2), 1009-1038. https://doi.org/10.1093/gji/ggw186

Pugh, D. J. \& White, R. S. (2018). MTfit: A Bayesian approach to seismic moment tensor inversion. Seismological Research Letters, 898, 1507-1513, https://doi/10.1785/0220170273

Reyes, C. G. \& West, M. E. (2011). The waveform suite: A robust platform for manipulating waveforms in MATLAB. Seismological Research Letter, 82(1), 104-110. https://doi.org/10.1785/gssrl.82.1.104

Reynolds, H. I., Gudmundsson, M. T., Högnadóttir, T., Magnússon, E., \& Pálsson F. (2017). Subglacial volcanic activity above a lateral dike path during the 2014-2015 Bárdarbunga-Holuhraun rifting episode, Iceland. Bulletin of Volcanology, 79(6), 38: 113. https://doi.org/10.1007/s00445-017-1122-z

Riel, B., Milillo, P., Simons, M., Lundgren, P., Kanamori, H., \& Samsonov, S. (2015). The collapse of Bárðarbunga caldera, Iceland. Geophysical Journal International, 202(1), 
446-453. https://doi.org/10.1093/gji/ggv157

Rodriguez-Cardozo, F. R., Hjörleifsdóttir, V., Jónsdóttir, K., \& Geirsson, H., (2017). Seismic Source parameters inversion for earthquakes in the Bardarbunga caldera pre and post 2014-2015 eruption. S41A-0737, AGU Fall Meeting, 2017.

Rossi, C., Minet, C., Fritz, T., Eineder, M., \& Bamler, R. (2016). Temporal monitoring of subglacial volcanoes with TanDEM-X : Application to the 2014-2015 eruption within the Bárðarbunga volcanic system, Iceland. Remote Sensing of Environment, 181, 186197. https://doi.org/10.1016/j.rse.2016.04.003

Ruch, J., Acocella, V., Geshi, N., Nobile, A \& Corbi, F. (2012). Kinematic analysis of vertical collapse on volcanoes using experimental models time series. Journal of Geophysical Research: Solid Earth, 117,B7 B07301. https://doi:10.1029/2012JB009229

Ruch, J., Wang, T., Xu, W., Hensch, M., \& Jónsson, S. (2016). Oblique rift opening revealed by reoccurring magma injection in central Iceland. Nature communications, 7 , 12352. https://doi.org/10.1038/ncomms12352

Saemundsson, K. (1978). Fissure swarms and central volcanoes of the neovolcanic zones of Iceland. In D. R. Bowes, B. E. Leake (Eds.), Geological Journal Special Issue, 10, $415-432$.

Segall, P., Llenos, A. L., Yun, S.-H. Bradley, A. M. \& Syracuse, E. M. (2013). Time-dependent dike propagation from joint inversion of seismicity and deformation data. Journal of Geophysical Research: Solid Earth, 11(118), 5785-5804. http://doi.org/10.1002/2013JB010251

Shelly, D. R., \& Hill, D. P. (2011). Migrating swarms of brittle-failure earthquakes in the lower crust beneath Mammoth Mountain, California. Geophysical Research Letters, 38(20), L20, 307. https://doi.org/10.1029/2011GL049336

Shuler, A., Ekström, G., \& Nettles, M. (2013). Physical mechanisms for vertical-CLVD earthquakes at active volcanoes. Journal of Geophysical Research: Solid Earth, 118(4), 1569-1586. http://doi.org/10.1002/jgrb.50131

Sigmarsson, O., Karlsson, H. R., \& Larsen, G. (2000). The 1996 and 1998 subglacial eruptions beneath the Vatnajökull ice sheet in Iceland: contrasting geochemical and geophysical inferences on magma migration. Bulletin of Volcanology, 61(7), 468-476. http://doi.org/10.1007/s004450000093

Sigmarsson, O., \& Halldórsson, S. A. (2015). Delimiting Bárðarbunga and Askja volcanic systems with Sr-and Nd-isotope ratios. Jökull, 65, 17-27. 
Sigmundsson, F., Hooper, A., Hreinsdottir, S., Vogfjord, K. S., Ófeigsson, B.

G., Heimisson, E. R., et al. (2015). Segmented lateral dike growth in a rifting event at Bárðarbunga volcanic system, Iceland. Nature, 517(7533), 191-195. https://doi.org/10.1038/nature14111

Spaans, K., \& Hooper, A. (2018). Insights Into the Stress Field Around Bárðarbunga Volcano From the 2014/2015 Holuhraun Rifting Event Journal of Geophysical Research: Solid Earthl, 123(4), 3238-3249. https://doi.org/10.1002/2017JB015274

Soosalu, H., Key, J., White, R. S., Knox, C., Einarsson, P., \& Jakobsdóttir, S. S. (2010). Lower-crustal earthquakes caused by magma movement beneath Askja volcano on the north Iceland rift. Bulletin of Volcanology, 72(1), 55-62. https://doi.org/10.1007/s00445009-0297-3

Svavarsdóttir, S. .I., Halldórsson, S. A., \& Guðfinnsson, G. H. (2017). Geochemistry and petrology of Holocene lavas in the Bárðardalur region, N-Iceland. Part I: Geochemical constraints on source provenance. Jökull, 67, 17-42.

Thordarson, T. \& Larsen, G. (2007). Volcanism in Iceland in historical time: Volcano types, eruption styles and eruptive history. Journal of Geodynamics, 43(1), 118-152. https://doi.org/10.1016/j.jog.2006.09.005

Tkalčić, H., Dreger, D. S., Foulger, G. R., \& Julian, B. R. (2009). The puzzle of the 1996 Bárðarbunga, Iceland, earthquake: No volumetric component in the source mechanism. Bulletin of the Seismological Society of America, 99(5), 3077-3085. https://doi.org/10.1785/0120080361

Trugman, D. T. \& Shearer, P. M. (2017). GrowClust: A hierarchical clustering algorithm for relative earthquake relocation, with application to the Spanish Springs and Sheldon, Nevada, earthquake sequences. Seismological Research Letters, 88(2A), 379-391. https://doi.org/10.1785/0220160188

Vinet, N., \& Higgins, M. D. (2010). Magma Solidification Processes beneath Kilauea Volcano, Hawaii: a Quantitative Textural and Geochemical Study of the 1969-1974 Mauna Ulu Lavas. Journal of Petrology, 51(6), 1297-1332. https://doi.org/10.1093/petrology/egq020

Waldhauser, F., \& Ellsworth, W. L. (2000). A double-difference earthquake location algorithm: Method and application to the northern Hayward fault, California. Bulletin of the Seismological Society of America, 90(6), 1353-1368. https://doi.org/10.1785/0120000006 
Walker, G. P. (1984). Downsag calderas, ring faults, caldera sizes, and incremental caldera growth. Journal of Geophysical Research: Solid Earth, 89(B10), 8407-8416. https://doi.org/10.1029/JB089iB10p08407/a

White, R. S., \& Mckenzie, D. (1989). Magmatism at rift zones: The generation of volcanic continental margins and flood basalts. Journal of Geophysical Research: Solid Earth, 94(B4), 7685-7729. https://doi.org/10.1029/JB094iB06p07685

White, R. S., Drew, J., Martens, H. R., Key, J., Soosalu, H., \& Jakobsdóttir, S. S. (2011). Dynamics of dike intrusion in the mid-crust of Iceland. Earth and Planetary Science Letters, 304(3-4), 300-312. https://doi.org/10.1016/j.eps1.2011.02.038

White, R. S., Maclennan, J., Greenfield, T., \& Ágústsdóttir, T. (2018). Melt movement through the Icelandic crust Proceedings of the Royal Society, Series A(377), 20180010. https://doi.org/10.1098/rsta.2018.0010

Wolfe, C. J., Bjarnason, I. T., VanDecar, J. C., Solomon, S. C. (1997). Seismic structure of the Iceland mantle plume. Nature, 6613, 245-247. https://doi.org/10.1038/385245a0

Woods, J., Donaldsson, C., White, R. S., Caudron, C., Brandsdóttir, B., Hudson, T. S., \& Ágústsdóttir, Th. (2018). Long-period seismicity reveals magma pathways above a laterally propagating dyke during the 2014-15 Bárðarbunga rifting event, Iceland. Earth and Planetary Science Letters, 490, 216-229. https://doi.org/10.1016/j.epsl.2018.03.020

Woods, J., Winder, T., White, R. S., Brandsdóttir, B. (2019). Evolution of a lateral dike intrusion revealed by relatively-relocated dike-induced earthquakes: The 2014-15 Bárðarbunga-Holuhraun rifting event, Iceland. Earth and Planetary Science Letters, 506, 53-63. https://doi.org/10.1016/j.epsl.2018.10.032

Wright, T. J., Sigmundsson, F., Pagli, C., Belachew, M., Hamling, I. J., Brandsdóttir, B., et al. (2012). Geophysical constraints on the dynamics of spreading centers from rifting episodes on land.Nature, 5(4), 242-250. https://doi.org/10.1038/ngeo1428

Thorarinsson, S., \& Sigvaldason, G. E. (1972). The Tröllagígar eruption 1862-1864. Jökull, 22, 12-26. 